\title{
GEOLOGIA E PETROLOGIA DAS ROCHAS METAMÓRFICAS E GRANITICAS ASSOCIADAS DO VALE DO RIO RIBEIRA DE IGUAPE, SP E PR
}

\author{
GERALDO C. MELCHER*, CELSO B. GOMES**, UMBERTO G. CORDANI**, \\ JORGE S. BETTENCOURT**, EDUARDO C. DAMASCENO*, VICENTE A. V. \\ GIRARDI** e ADOLPHO J. MELFI**
}

\begin{abstract}
An area of 16900 square kilometers, located between $48^{\circ}$ to $49^{\circ} 30^{\prime}$ west longitude and $24^{\circ}$ to $25^{\circ}$ south latitude, was geolengically mapped in $1: 100.000$ scale.

Flat lying Devonian and Permo-carboniferous sediments occur in the northern part of the region, but most of the area is underlain by late Precambrian and Eopalaeozic igneous and metamorphic rocks.

Argillaceous low grade metasediments are widespread, although typical phyllites are subordinate. These rocks usually exhibit clear bedding planes and contain dominant sericite and quartz. Graphite, magnetite, apatite, tourmaline, rutile, and epidote are acessories. A variety of micaschists occurs in different parts of the area. Quartz and muscovite are the main minerals, but also biotite, chlorite, garnet, staurolite, kyanite, and hornblende may occur in various proportions. Apatite, sphene, zircon, rutile, and opaque minerals are accessories. Metamorphic rocks derived from siltstones and sandstones contain essentially the same minerals, but occasionally feldspars are abundant in these rocks. True quartzites form some of the more conspicuous ridges in the area. Subordinate conglomerate lenses are also found. Limestones, dolomites and carbonate schists occur in three main belts in the area. Usually individual layers of carbonate minerals are from a few centimeters to one meter thick and alternate with thin sandy or micaceous beds. Impure limestones have produced a large variety of carbonate schists which may contain carbonate, quartz, tremolite, garnet, actinolite, hornblende, phlogopite, plagioclase, microcline, diopside, epidote, sphene, tourmaline, scapolite, and opaque minerals. Many occurrences of amphibolites and amphibole schists are intercalated in the metasediments, but they are mostly too small to be mapped. The amphibolites contain, almost exclusively, common green hornblende and andesine. Gneisses and migmatites are the dominant rocks in the southern part of the area. Some migmatites are quite homogeneous and contain mostly quartz and feldspar with subordinate irregular bands of biotite. Typical banded gneisses are also found.

The metamorphic rocks are cut by many granitic bodies of different sizes, ranging from small stocks only a few hundreds of meters in diameter to large batholiths. With one single exception, the Itapeúna massif, they represent late or post tectonic intrusions. The most common variety is a porphyroidal granite which contains large microcline crystals in a much finer matrix of feldspars, quartz, biotite, and hornblende. In the southern part of the area several granite bodies, occur with alkaline affinities. These rocks are made up essentially by orthoclase, oligoclase, quartz, biotite, and some hornblende or a more sodic amphibole. Granite porphyries occur as dykes or small stocks.

A large part of the rocks that belong to the Açungui Group were submitted to a low grade metamorphism, corresponding to the green schist facies. Many original sedimentary features are still preserved and schistosity is only incipient.

In the southern part of the area, a stronger degree of regional metamorphism affected the rocks and produced mineral assemblages which include biotite, garnet, staurolite, and kyanite. A progressive increase in the intensity of the regional metamorphism, from northwest to southeast, can clearly be observed. Near the borders of some granitic intrusions contact or thermal metamorphism produced mineral assemblages which correspond to the albite-epidote hornfels, hornblende hornfels or pyroxene hornfels facies. Retrograde metamorphism apparently took place in limited zones that were deformed after the main period of metamorphism.
\end{abstract}

*Escola Politécnica da Universidade de São Paulo, Caixa Postal, 8174, São Paulo, SP

**Instituto de Geociências da Universidade de São Paulo, Caixa Postal 20 899. São Paulo, SP 
During the main orogeny compressive forces ácted predominantly along an axis oriented NW-SE and produced a wide variety of structural features. Tight apparently isoclinal folds are very common in the area and the prevailing strike is to NE. Extensive thrust faults also occur. A younger system of fractures and gravity faults is oriented to NW.

Radiometric age determinations indicate that most metamorphic rocks of the area were deposited during the Brasiliano geotectonic cycle (about 650 m.y. ago), although some older rocks are also found. The large porphyroidal granite batholiths were intruded between $650-600 \mathrm{~m}$. y. Post tectonic granites are $540 \mathrm{~m}$. y. old.

INTRODUçÃo Desde o século passado, a região do Vale do Rio Ribeira de Iguape vem sendo objeto de numerosas investigações geológicas. Algumas dessas pesquisas, talvez mesmo a sua maior parte, consistiram no exame de ocorrências minerais, $\cdot$ da mais variada natureza, ali encontradas, enquanto que outras, de caráter essencialmente científico, visaram ao esclarecimento de problemas estratigráficos, estruturais e petrológicos relacionados às formações geológicas. Publicações especializadas, em número superior a duas centenas, ainda que grandemente dispersas na literatura geológica ou integrando relatórios inéditos, atestam a importância dos problemas geológicos reconhecidos e o volume de trabalho dedicado à sua solução. No entanto, a quase totalidade dessa literatura, principalmente a mais antiga, volta-se para aspectos locais, pouco oferecendo assim ao conhecimento global da geologia pré-cambriana da região.

Coube a Melcher e Johnson (1956) a iniciativa pioneira de levantar geologicamente parte da área investigada, visando ao conhecimento das formações pré-cambrianas e suas possibilidades minerais. Posteriormente, Melfi et al. (1965), com base em interpretações fotogeológicas, forneceram uma visão global da geologia de vasta região (aproximadamente $20000 \mathrm{~km}^{2}$ ), correspondente à porção meridional do Estado de São Paulo. Por outro lado, a parte limítrofe paranaense foi amplamente pesquisada, nos mais variados aspectos geológicos, por Fuck et al. (1967), Marini et al. (1967) e Fuck et al. (1971). Petri e Suguio (1969) estudaram pormenorizadamente os metassedimentos que afloram entre os paralelos $24^{\circ} 00^{\prime}$ e $24^{\circ} 50^{\prime s}$, e meridianos $48^{\circ} 00^{\prime}$ e $48^{\circ} 30^{\prime}$ W. Gr., buscando obter dados a respeito dos ambientes de formação e processos de sedimentação dessas rochas. Informações adicionais sobre o pré-cambriano da Ribeira, com maior enfoque para os seus recursos minerais, são também encontradas em Melcher (1968).

O mapeamento geológico referente ao Projeto Ribeira foi executado pela PROTEC - Projetos Técnicos e Obras de Engenharia Ltda. - para o Departamento Nacional da Produção Mineral. O seu principal objetivo consistiu na elaboração de seis cartas geológicas adjacentes (Apiaí, Capão Bonito, Cerro Azul, Eldorado. Guapiara e Itararé), em escala 1:100000, cobrindo área de aproximadamente $16900 \mathrm{~km}^{2}$, compreendida entre os paralelos $24^{\circ} 00^{\prime}$ e $25^{\circ} 00^{\prime}$ e meridianos $48^{\circ} 00^{\prime}$ e $49^{\circ} 30^{\prime}$ W. Gr. Para a elaboração da base cartográfica utilizada no mapa geológico, contou-se com material proveniente das seguintes fontes: (a) mapas planimétricos, escalas 1:10000 e 1:50 000, PROSPEC, Levantamentos, Prospeç̧ões e Aerofotogrametria, serviço 134; (b) mapas altimétricos, escala 1:10000, Serviços Aerofotogramétricos Cruzeiro do Sul; (c) mapas planimétricos, escala 1:50 000, feitos pela PROTEC usando-se triangulação radial e fotografias aéreas da LASA, Levantamentos Aerofotogramétricos S.A., nas escalas 1:25000 1:70000.

Essas cartas geológicas foram publicadas, na escala $1: 200000$, nos Anais do XXV Congresso Brasileiro de Geologia (Melcher et al., 1971; Bettencourt et al., 1971; Gomes et al., 1971a; Cordani et al., 1971a; Cordani et al., 1971b; Gomes et al., 1971b).

Para informações mais pormenorizadas sobre a geologia da área, os mapas originais devem ser consultados. 


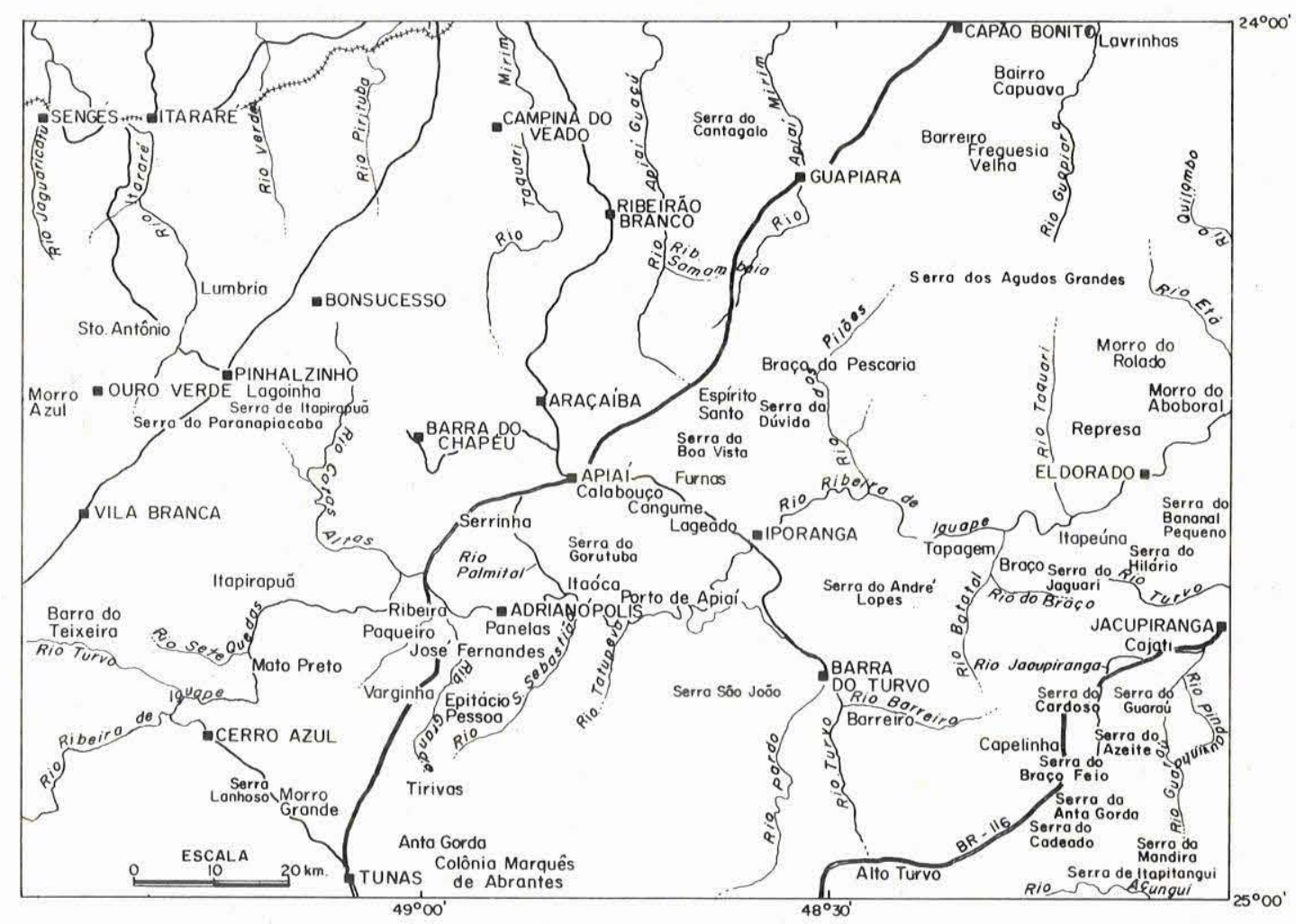

Figura 1 - Mapa indicativo das localidades referidas no texto

Geologia regional A Fig. 2 foi elaborada a partir das folhas em escala 1:200000 mencionadas no capítulo anterior. Nela aparecem apenas as unidades litológicas mapeáveis, de acordo com a escala adotada, tendo sido efetuadas as simplificações adequadas. No total, foram visitados pelos autores, na região investigada, mais de 5000 afloramentos, e foram estudadas diversas centenas de seções delgadas das rochas regionais. Os principais acidentes geográficos da área acham-se resumidos na Fig. 1.

Rochas metamórficas pertencentes ao Grupo Açungui e Complexo Cristalino constituem, juntamente com os maciços graníticos, as litologias dominantes na região da Ribeira (veja Fig. 2). Essas rochas, que serão descritas pormenorizadamente nos capítulos seguintes, distribuem-se por toda a área mapeada, à exceção apenas da sua porção noroeste, onde apresentam-se cobertas por sedimentos paleozóicos.

Neste capítulo serão tratadas, em grandes traços, as características das demais rochas encontradas na região, notadamente os sedimentos que pertencem à borda oriental da Bacia do Paraná e as rochas magmáticas basálticas e alcalinas pós-paleozóicas que cortam os metassedimentos.

As rochas sedimentares, de ocorrência restrita às folhas de Itararé e Guapiara, acham-se representadas principalmente por meio de camadas sub-horizontais pertencentes à Formação Furnas e ao Grupo Tubarão, de idades, respectivamente, devoniana e permocarbonífera (Petri e Fúlfaro, 1967).

Os sedimentos da Formação Furnas, constituindo a seqüência inferior do devoniano na Bacia do Paraná, consistem em arenitos, por vezes arcozianos, de granulação média a grossa, com algumas intercalações locais conglomeráticas e outras siltosas. A estratifi- 
cação é plana, com disposição geralmente subparalela das camadas e limites ondulados. Algumas intercalações são portadoras de estratificação cruzada. Na maior parte das ocorrências, o arenito Furnas assenta-se direta e discordantemente sobre um peneplano estabelecido sobre as rochas pré-devonianas e forma escarpas abruptas, com várias dezenas de metros de desnível. Apenas em algumas localidades, observa-se a presença de um conglomerado basal, contendo seixos de quartzo e quartzito. rom espessura não superior a $80 \mathrm{~cm}$.

A exemplo do observado na Formação Furnas, arenitos representam a litologia principal do Grupo Tubarão na área investigada. Suas características petrográficas são muito similares às dos sedimentos descritos atrás, tornando-se dessa forma difícil distingui-los prontamente no campo. Segundo Petri e Fúlfaro (1967), isto resulta em grande parte do fato de as camadas permocarboníferas serem constituídas de material devoniano retrabalhado.

O Grupo Tubarão assenta-se em discordância erosional sobre os arenitos da Formação Furnas, cuja superfície apresenta algumas ondulações irregulares. Observa-se isso, por exemplo, ao longo da rodovia Itararé-Sengés, onde ocorrem os mais característicos afloramentos de tilitos, sobrepostos a siltitos com algumas intercalações arenosas. Em outros trechos, os sedimentos permocarboníferos transgridem sobre o embasamento cristalino, preenchendo calhas erodidas na sua superfície. Nas áreas onde o Grupo Tubarão assenta-se sobre rochas metamórficas, é comum a ocorrência de um conglomerado fluvioglacial na sua base.

Em alguns locais da área, a seqüência permocarbonífera inicia-se por folhelhos cinzentos, contendo alguns pequenos seixos e delgadas intercalações de arenitos finos. Tais folhelhos possuem poucos metros de espessura e são sucedidos por siltitos conglomeráticos semelhantes a tilitos, pouco espessos, seguindo-se então arenitos grossos com aspecto semelhante ao dos arenitos Furnas. Morfologicamente, esses arenitos também formam escarpas verticais de aspecto idêntico à dos arenitos devonianos.

O embasamento pré-cambriano da área, assim como os sedimentos paleozóicos, mostra-se recortado por numerosos diques de diabásio, subverticais, orientados preferencialmente segundo N45W. Esses diques, em geral com extensão de alguns quilômetros, distribuem-se por toda a área, conquanto apresentem uma zona de maior concentração junto à sua porção nordeste (Guapiara e imediações). Essa atividade magmática é parte integrante do vulcanismo basáltico que afetou o Brasil meridional durante o Mesozóico. Duas intrusões de gabro, Apiaí e José Fernandes, foram também assinaladas na região. A primeira é filiada ao magmatismo basáltico, e a segunda parece ser pouco anterior, como é evidenciado por determinações radiométricas.

A área da Ribeira viu-se também afetada por uma nova atividade magmática mesozóica, porém de natureza alcalina e de duração aparentemente compreendida pelo intervalo 60-135 m.a. (Gomes e Cordani, 1965; Amaral et al., 1967; Cordani e Hasui, 1968). Esse magmatismo, responsável por algumas ocorrências minerais da região, tem como principais representantes os maciços de Jacupiranga, Tunas e Itapirapuã. Corpos menores, provavelmente jazendo na forma de pequenas chaminés vulcânicas, acham-se exemplificados pelas ocorrências de Mato Preto, Sete Quedas e Barra do Teixeira.

Sedimentos cenozóicos, ainda em processo de formação junto aos principais rios que drenam a região, constituem a litologia mais recente do vale da Ribeira. Excluídos os terraços fluviais assinalados na folha de Eldorado, que foram objeto de citação e discussão por Silveira (1950), Bigarella e Mousinho (1965) e Franzinelli (1970, 1971), os demais depósitos não possuem expressão geográfica, restringindo-se apenas a camadas de pequena espessura, em geral situadas pouco acima do nível atual dos rios e formando depósitos de várzeas. São sedimentos inconsolidados e constituídos principalmente de siltes, argilas 
e areias de diversas granulações. Mais raramente aparecem leitos de cascalho, com seixos formados de quartzo e quartzito.

Geologia e petrografia das rochas metamórficas A maior parte da região investigada é formada por rochas metamórficas, com fácies de metamorfismo entre xistos verdes e anfibolito, às quais se associam diversos complexos graníticos intrusivos, de distribuição irregular, variáveis em forma e dimensão (veja Fig. 2).

As rochas de grau de metamorfismo mais baixo guardam continuidade física com as que foram descritas mais para o Sul, no Estado do Paraná, e que constituem o Grupo Açungui s.s. As rochas gnáissicas e migmatíticas, entretanto, são de mais difícil caracterização, motivo pelo qual torna-se oportuno analisar as relações entre os dois conjuntos de rochas metamórficas, tanto na região estudada como na região adjacente mapeada pelos geólogos da Comissão da Carta Geológica do Paraná (Marini et al., 1967).

No trabalho referido no paragráfo anterior, aqueles autores adotam uma subdivisão do Grupo Açungui em quatro formações, sendo as três superiores (Formações Água Clara, Votuverava e Capiru) de fácies xistos verdes, enquanto que a inferior (Formação Setuva) de fácies anfibolito. Todo este conjunto, que constituiria uma única unidade geotectônica, é colocado estratigraficamente acima de um embasamento gnáissico e migmatítico, denominado de Complexo Cristalino, cujas rochas enquadram-se, em sua maior parte, na fácies anfibolito (Fuck et al., 1967).

Uma nítida discordância angular, visível sobre o terreno, foi assinalada entre as Formações Setuva e Capiru. Entretanto, contatos predominantemente tectônicos impediram a melhor caracterização de discordâncias entre as demais formações, e mesmo entre o Grupo Açungui, como foi definido por aqueles autores, e o Complexo Cristalino. O tectonismo intenso impediu também úma avaliação criteriosa das espessuras das formações acima descritas. Marini et al. (1967) consideram da ordem 'de 10000 metros a espessura global do Grupo Açungui (incluindo a Formação Setuva, a espessura desta estimada em 2500 metros).

As relações de campo observadas pelos presentes autores na região do Ribeira confirmam em parte as observações dos geólogos da Comissão da Carta Geológica do Paraná. As unidades litológicas mapeáveis encontradas pelas duas equipes de trabalhos de campo são perfeitamente correlacionáveis. Além disso, os mapas geológicos apresentados independentemente para as mesmas regiões (por exemplo, região da folha de Cerro Azul) apresentam-se essencialmente comparáveis.

Entretanto, quanto à parte interpretativa dos mapeamentos e especificamente sobre as relações de campo entre os metassedimentos epizonais e o conjunto gnáissico-migmatítico, cabe ressaltar o seguinte:

1) Na região do Rio Turvo, no perfil entre Barra do Turvo e a BR-116, parece haver passagem gradual entre os filitos e micaxistos, que pertencem ao Grupo Açungui, e as rochas gnáissicas que integram o assim chamado Complexo Cristalino. Em particular, algumas camadas de rochas carbonáticas aparecem intercaladas em gnaisses fitados e migmatitos. Esse fato parece demonstrar que, pelo menos em parte, o Complexo Cristalino representa material co-genético ao Grupo Açungui s.s., apenas metamorfoseado regionalmente em grau mais alto.

2) Algumas determinações radiométricas em rochas da Formação Setuva parecem evidenciar, para tais litologias, idades bem mais antigas do que as obtidas para as demais variedades petrográficas do Grupo Açungui. Esse fato já foi notado por Marini et al. (1967) ao comentar um dado K-Ar obtido no laboratório de Cambridge. Acresce que relações 
estruturais levaram Fuck et al. (1971) e Ebert (1971) a considerar as rochas da Formação Setuva como constituindo o embasamento retrabalhado do geossinclinal "Açungui" e pertencendo, portanto, a um ciclo mais antigo.

3) O mesmo tectonismo intenso que afetou a região paranaense foi também encontrado pelos presentes autores na região da Ribeira, dificultando as observações dos contatos entre as unidades litológicas.

Essas considerações mostram que o problema de uma subdivisão estratigráfica das rochas metamórficas da região da Ribeira está longe de ser resolvido. Apenas estudos geocronológicos mais intensos e mapeamentos pormenorizados em áreas convenientes poderão eventualmente elucidar a evolução completa da região. Para o presente trabalho, os autores preferem apresentar os dados geológicos e petrográficos obtidos, sem procurar interpretar as relações estratigráficas dos metamorfitos regionais. Correlações com as formações definidas por Marini et al. (1967) serão apresentadas no decorrer do trabalho, quando for julgado conveniente.

Neste capítulo serão descritos inicialmente os metassedimentos epizonais pertencentes seguramente ao Grupo Açungui, definido no Estado do Paraná, e que se distribuem em três seqüências litológicas distintas:

a) argilosa, representada por filitos e micaxistos;

b) arenosa, caracterizada por quartzitos, meta-arenitos e metaconglomerados;

c) carbonática, formada de calcários e dolomitos e contendo subordinadamente calcoxistos.

A seguir, os anfibolitos e anfibólioxistos associados às metamórficas epizonais serão objeto de descrição individualizada e, finalmente, serão consideradas no mesmo item as rochas gnáissicas e migmatíticas, que se constituem em parte no embasamento das rochas epizonais e, em outra parte, no material equivalente a estas últimas, mas metamorfoseado regionalmente em grau mais elevado.

Sequiência argilosa Filitos e micaxistos constituem as variedades dominantes. Em alguns casos, rochas gnáissicas aparecem como transformações graduais e serão caracterizadas no item "Gnaisses e Migmatitos". Em linhas gerais, poder-se-ia dizer que os termos filíticos distribuem-se irregularmente por toda a área, enquanto que os micaxistos são mais abundantes junto à sua porção meridional, especificamente nas folhas de Apiaí e Eldorado.

FILITOS Face à grande extensão da área, bem como a natureza do trabalho executado, antes visando um reconhecimento geral que se atendo a problemas específicos, o termo filito foi aqui empregado num sentido descritivo para caracterizar rochas metamórficas de baixo grau de metamorfismo, de granulação fina, e mesmo portadoras de feições petrográficas comuns a metassiltitos, meta-argilitos e, mais raramente, meta-arenitos. Dessa forma, pode-se afirmar que grande parte da área mapeada como filito é, em realidade, constituída de metassedimentos cíclicos e metarritmitos, tal como definiram Petri e Suguio (1969). Filitos típicos aparecem em pequena proporção.

Do ponto de vista mineralógico, essas rochas compõem-se dominantemente de quartzo e sericita, aparecendo grafita, magnetita, apatita, turmalina, rutilo e epídoto como principais acessórios. Ocasionalmente, são também portadoras de clorita, de hábito similar e dispondo-se de maneira idêntica à sericita.

A coloração varia desde cinza-claro a preto, não faltando tonalidades esverdeadas e avermelhadas, decorrentes da ação intempérica. A granulação é fina e a textura predominantemente lepidoblástica. Estrutura porfiroblástica foi reconhecida em várias amostras, 
merecendo registro especial, face à singularidade da paragênese, as ocorrências encontradas em alguns cortes da estrada ligando as localidades de Apiaí a Iporanga e as da Serra da Dúvida, em local não muito distante da sede do Instituto Geográfico e Geológico. As rochas da primeira ocorrência são portadoras de porfiroblastos de otrelita (variedade de cloritóide), de hábito placóide e dimensões milimétricas, enquanto que as da segunda, aflorando nas proximidades de um stock granítico, exibem andaluzita, presentemente alterada em sericita, em sua composição.

A estratificação é reconhecível macroscopicamente, em muitas ocorrências, pela alternância de leitos de diferente coloração e composição. A espessura dos leitos varia entre poucos milímetros e alguns centímetros. A xistosidade é quase sempre perceptível, mostrando-se ora paralela, ora inclinada relativamente ao acamamento.

MICAXISTOS Essas rochas diferem texturalmente das anteriores pelo desenvolvimento mais acentuado da estrutura xistosa, imprimindo-lhes feições onduladas e corrugadas em substituição à perfeita laminação dos filitos. A granulação é mais grossa, permitindo assim, à vista desarmada, o pronto reconhecimento dos seus constituintes minerais. No seu conjunto, a textura é marcadamente lepidoblástica, porém as zonas mais quartzosas, quando examinadas individualmente, mostram seu caráter granoblástico. Estruturas porfiroblásticas são freqüentes, enquanto que a estratificação ainda é reconhecível pela alternância de leitos claros e escuros, denotando maior ou menor riqueza em quartzo, ou por variações na granulação.

Confrontados com os filitos, os micaxistos exibem maior diversidade mineralógica. Ao lado de quartzo e muscovita, esta última substituindo a sericita, foram identificados biotita, clorita, granada, estaurolita, cianita, talco, pirofilita e hornblenda, além dos acessórios apatita, titanita, zircão, rutilo e opacos. Como principais produtos de alteração, foram reconhecidas calcita, serpentina e clorita, sendo que em algumas variedades a proporção desta última é muito grande, levando conseqüentemente à formação de verdadeiros cloritaxistos. Granada, biotita e estaurolita são os porfiroblastos mais comuns, com o primeiro mineral assumindo caráter poiquiloblástico na maior parte das vezes, tendo quartzo e opacos como principais inclusões. Em geral, os porfiroblastos são cristais idiomórficos e de dimensões milimétricas, com referência especial para as ocorrências do vale do Ribeirão Grande, poucos quilômetros ao sul da localidade de Paranaí.

Os micaxistos porfiroblásticos acima descritos foram enquadrados, por Marini et al. (1967), dentro da Formação Setuva.

Passagem gradual dos filitos aos micaxistos, provavelmente como resultado de elevação do gradiente metamórfico regional, foi observada ao longo de alguns perfis na área investigada, com as melhores exposições concentradas ao longo da estrada Iporanga- Barra do Turvo.

Sequiência arenosa Os metassedimentos arenosos possuem sua maior expressão areal nas folhas de Itararé, Guapiara e Apiaí. Parecem concentrar-se em determinado nível estratigráfico, em associação com rochas dolomíticas, o que mais para o sul caracteriza a Formação Capiru de Marini et al. (1967). Petri e Suguio (1969), analisando o comportamento dos metassedimentos em tal região, ressaltam a maior concentração desses termos junto à parte norte do extenso batólito granítico Três Córregos, que corta quase que diagonalmente o mapa geológico da Fig. 1.

À exceção dos verdadeiros quartzitos e metaconglomerados, que serão descritos a seguir, os metassedimentos arenosos têm por principal característica a alternância de estratos arenosos com intercalações de material argiloso e, mais raramente, carbonático. 


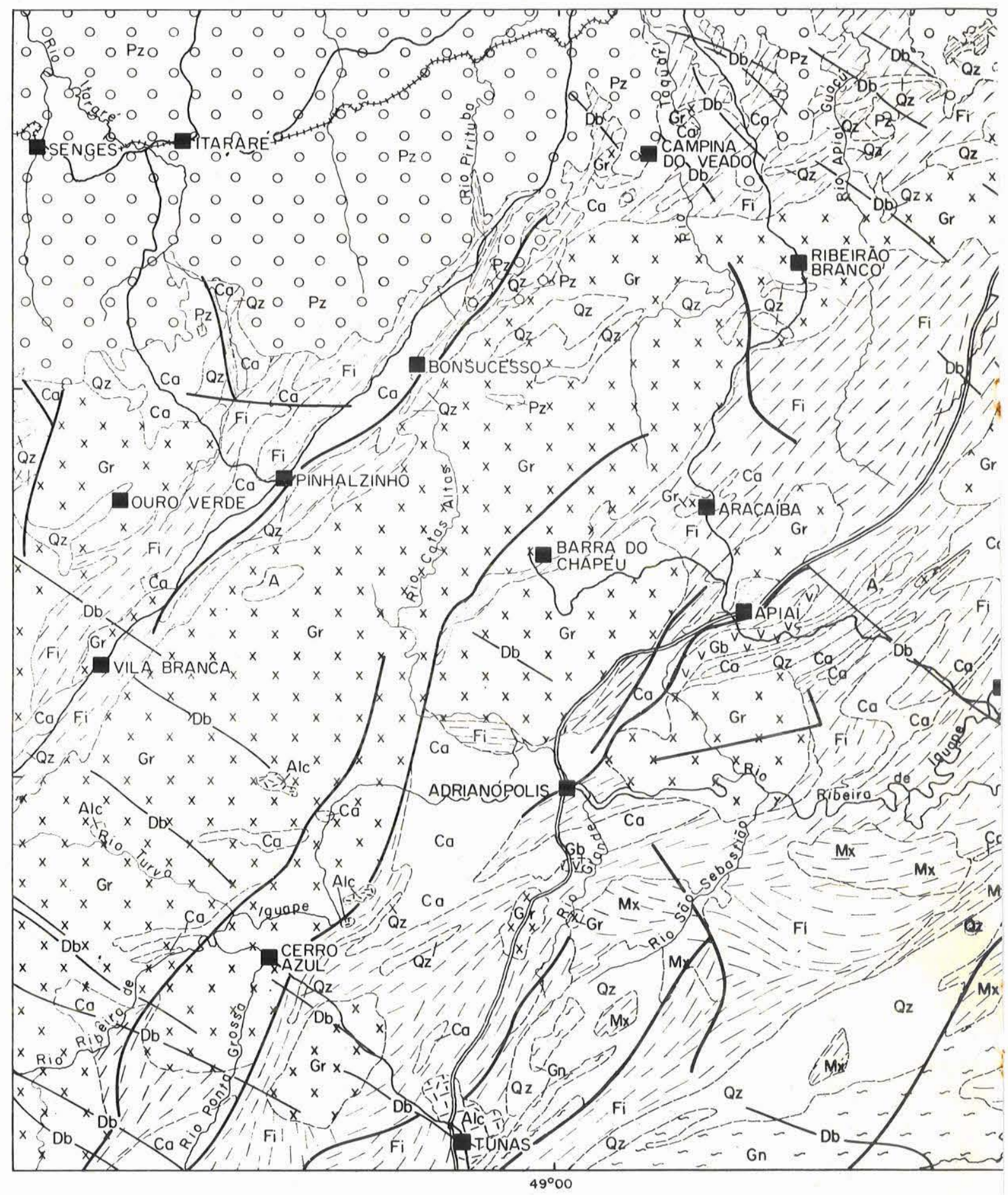

Figura 2 - Mapa geológico 


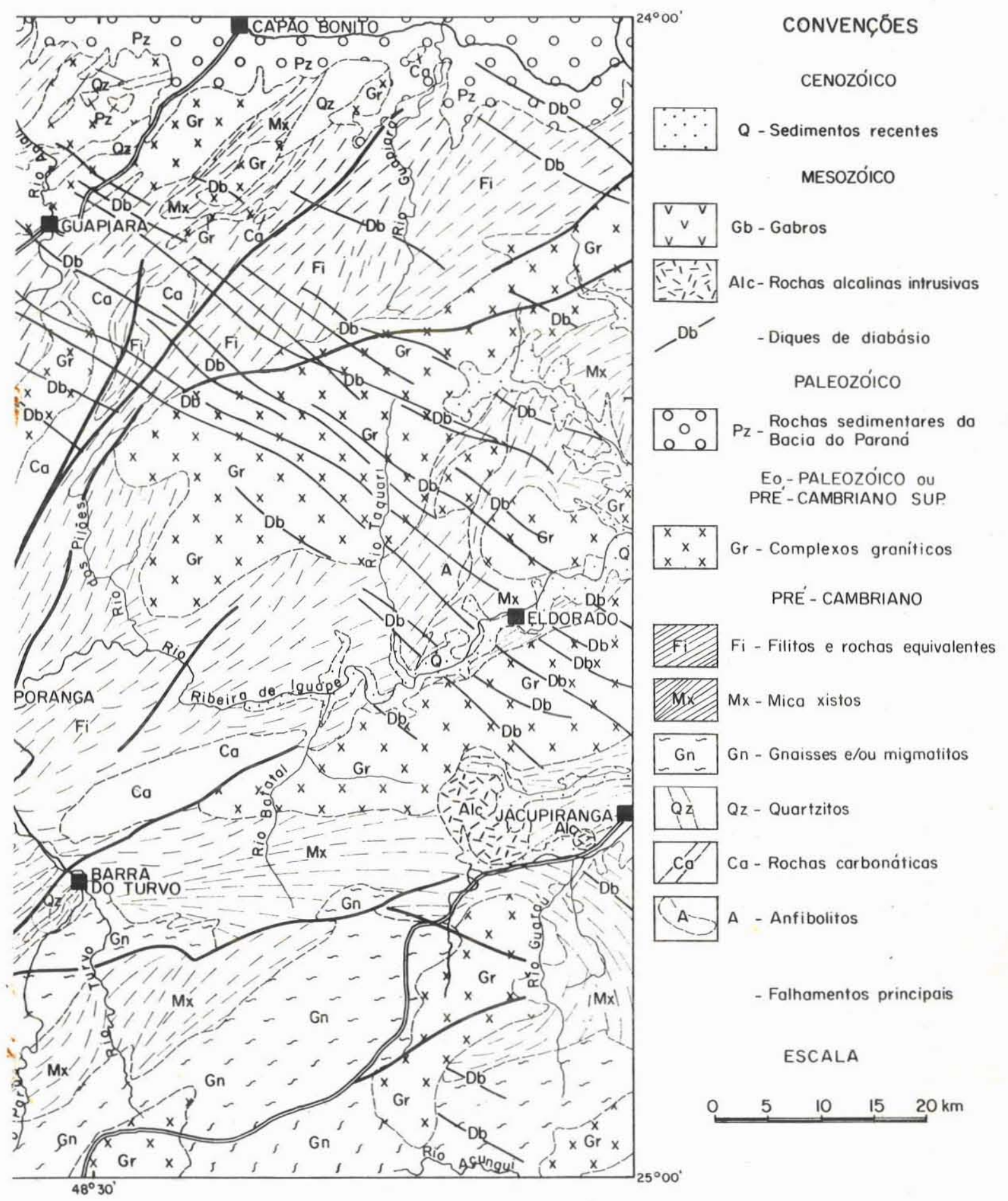

o vale do Ribeira do Iguape 
Os estratos arenosos acham-se representados por meta-arenitos, por metassiltitos, ou mesmo por uma associação de ambos.

Quartzo e sericita, variando em proporção e disposição no interior das rochas, são os minerais dominantes, aparecendo esporadicamente calcita e clorita. A presença de minerais micáceos confere a essas rochas incipiente xistosidade, em geral concordante ou levemente discordante da estratificação. Ocasionalmente, são portadoras de alta concentração de feldspatos alcalinos e/ou plagioclásios, parcial ou inteiramente intemperizados, assumindo então composição de meta-arcózios. Nestas condições, a composição mineralógica vê-se também enriquecida em alguns minerais ferromagnesianos, tais como biotita, epídoto, hornblenda etc. Embora não mapeáveis, merecem citação as ocorrências de meta-arcózios situadas ao longo de alguns cortes das estradas Furnas-Iporanga e Paranaí-Adrianópolis, estas últimas junto à barra do Rio Tatupeva.

QUARTZITOS Verdadeiros quartzitos foram também assinalados, sobretudo nas folhas de Itararé, Guapiara e Apiaí. Âs vezes constituem camadas homogêneas de grandes espessuras, como nas Serras dè Itapirapuã, Paranapiacaba, Cantagalo, São João, Anta Gorda e Boa Vista. Ocorrem também na forma de enclaves, variando, em extensão, de algumas centenas de metros até 2 a $3 \mathrm{~km}$, no interior dos maciços graníticos, particularmente nos de Três Córregos, região Bonsucesso-Ribeirão Branco, e Cunhaporanga, adjacências de Ouro Verde.

Texturalmente, têm por principais características o fabric marcadamente granoblástico e a granulação fina a grossa, com as dimensões dos grãos oscilando entre $0,3 \mathrm{e}$ 2,0 mm. A coloração é branca a cinzanclara, todavia tonalidades mais escuras e mesmo avermelhadas, função direta da quantidade e estado de alteração dos minerais escuros presentes, têm sido também observadas. A recristalização parece ter atuado em intensidade variada nessas rochas, reconhecendo-se amostras exibindo os mais diversos estádios de deformação e neoformação de minerais. $\mathrm{Na}$ maior parte das vezes, os cristais são equidimensionais, de contornos denteados, porém, em algumas amostras, ainda são visíveis feições indicativas da antiga textura do sedimento original, representadas pelo grau distinto de arredondamento a que foram submetidos os grãos de quartzo e no caráter mal selecionado do sedimento. As amostras mais tectonizadas exibem cristais alongados na direçăo da xistosidade.

Além do quartzo, mineral dominante, encontram-se igualmente presentes magnetita, hematita, limonita, zircão e rutilo, esse último na forma de agulhas inclusas nos cristais de quartzo. Muscovita é o principal mineral acidental, entremeando-se aos grãos de quartzo. Nas amostras mais orientadas, dispõe-se preferencialmente no plano de xistosidade, isoalinhando-se êntão com relativa freqüência.

METACONGLOMERADOS Rochas metamórficas conglomeráticas, não mapeáveis na escala cartográfica adotada, foram reconhecidas em diversos pontos da área, com as melhores exposições situadas na estrada Apiaí-Iporanga nas proximidades dos marcos quilométricos 349,356 e 358 . Essa última ocorrência foi originalmente descrita por Leonardos (1934). Metaconglomerados aparecem também junto às margens do Ribeirão Samambaia, em local distante aproximadamente $8 \mathrm{~km}$, por estrada secundária, do marco 279 da rodovia Guapiara-Apiaí. Ocorrências menos expressivas são encontradas na mesma estrada porém a $1 \mathrm{~km}$ do marco 279, bem como nas margens do Rio Apiaí-Guaçu, algumas centenas de metros ao sul da barra do Ribeirão Samambaia. Descrições pormenorizadas desses metaconglomerados são fornecidas em Petri e Suguio (1969). Segundo esses autores, tais rochas acham-se representadas por dois tipos distintos: oligomíticos e polimíticos. 
Os oligomíticos são constituídos de seixos de quartzo e de metassedimentos, principalmente quartzitos, que passam gradativamente para termos arenosos e mesmo sílticos. A relação seixos: matriz é variável, porém em geral muito alta. A matriz é mal selecionada, enquanto que os seixos, bem e mal arredondados, possuem dimensões pequenas, com valores médios da ordem de 2 a $4 \mathrm{~mm}$. Segundo Petri e Suguio (1969), a espessura da seqüência gradativa é diretamente proporcional ao tamanho dos seixos ou grânulos predominantes. São mais comuns espessuras de poucus centímetros, podendo atingir um metro. O contato inferior dos metaconglomerados é erosivo, mas as irregularidades são de pequena amplitude.

Os polimíticos, aparentemente menos comuns que os anteriores, possuem seixos grandes, da ordem de vários centímetros, bem arredondados e de natureza variável. Foram reconhecidos fragmentos de quartzo, de metassedimentos regionais (quartzitos, filitos, xistos, calcários etc.), de rochas graníticas e mesmo de feldspatos. A proporção dos seixos é muito grande, ao redor de 70 a $80 \%$, enquanto que a matriz possui natureza sericítica, clorítica ou mesmo arcoziana. A espessura dos horizontes de metaconglomerados é variável, ainda que, no seu conjunto, seja maior do que no primeiro tipo (Petri e Suguio, 1969).

Seqüência carbonuiica Essa seqüência acha-se representada na área mapeada por três faixas principais, de direção aproximadamente nordeste, que se estendem continuamente por vários quilômetros. A primeira delas, estendendo-se desde Vila Branca, Paraná, até Campina do Veado, São Paulo, e abrangendo parte das folhas de Cerro Azul e Itararé, possui composição essencialmente dolomítica e guarda correspondência direta com a Formação Itaiacoca, de Almeida (1957), incluída por Bigarella e Salamuni (1958) e por Marini et al. (1967) na Formação Capiru. A segunda faixa inicia-se perto de Cerro Azul, alcançando as imediações do lugarejo Casa da Pedra, não muito distante de Guapiara, já na folha de Capão Bonito, São Paulo. Sua composição é predominantemente calcária e, estratigraficamente, corresponde ì Formaçào Votuverava, de Marini et al. (1967). A terceira faixa, de menor expressão que as anteriores e ocupando parte das folhas de Apiaí e Eldorado, estende-se desde as proximidades da localidade de Barra de Turvo até um pouco a norte de Braço. Sua composição é de dolomito silicoso, não obstante seja por vezes referida como calcário da Tapagem.

CALCÁRIOS As rochas calcárias ocorrem, na área investigada, formando camadas contínuas, com espessura variável de algumas dezenas a centenas de metros, estendendo-se dominantemente na direção lés-nordeste-oés-sudoeste por vários quilômetros. Entretanto, em muitos casos, aparecem como intercalações em associação íntima com filitos e quartzitos, sendo seus contatos nitidamente concordantes. Em algumas dessas ocorrências, por exemplo, na mina de Furnas, tem lugar o aparecimento de calcário com aspecto brechóide na zona de contato entre essas formações, levando a pensar-se na existência de uma eventual ação tectônica. Por vezes, as rochas calcárias apresentam-se fraturadas e recristalizadas, com a recristalização atuando de maneira mais efetiva ao longo dos planos de fraturas e superfícies de separação dos estratos.

Em geral, a estratificação é reconhecível macroscopicamente pela alternância irregular de estratos com espessuras variáveis de alguns milímetros a vários centímetros, distinguindo-se sobretudo por sua cor. Antigas feições sedimentares, parcialmente preservadas, são ainda visíveis em diversas ocorrências, tornando-se possível identificar estruturas aparentando marcas de ondas, ao lado de outras indicativas de estratificação diagonal e gradacional. Dobras de arrasto, de pequena amplitude e resultantes do deslizamento entre camadas de 
diferente competência, têm sido observadas com freqüência. Estruturas de dissolução, caracterizadas pela presença de ondulações centimétricas desenvolvidas principalmente sobre os planos de estratificação, constituem também feições comuns. Em afloramentos parcialmente intemperizados, é possível verificar-se a relativa freqüência com que intercalações de outros metassedimentos, sobretudo filitos e micaxistos e subordinadamente quartzitos, estão presentes nas rochas calcárias da região. Várias ocorrências de tetos pendentes (roof pendants) foram também observadas na área investigada. Nestas, as rochas carbonáticas formam massas irregulares que se dispõem erraticamente no interior de corpos graníticos.

Quando pouco movimentadas e metamorfoseadas, as rochas calcárias regionais apresentam coloração escura em tonalidades que variam desde cinza a preto, embora variedades azuladas sejam comuns. Acredita-se que tal coloração seja devida à presença de pequenos cristais no interior das rochas (Melcher, 1968). De maneira geral, os calcários possuem granulação fina, por vezes finíssima a ponto de não serem reconhecidos à vista desarmada os seus constituintes minerais, tornando-se grossa ao longo de zonas de fraturamento, movimentação e proximidades dos corpos intrusivos. Nas vizinhanças de intrusões graníticas, como, por exemplo, em Panelas, Serrinha, Porto de Apiaí, Cangume etc., os calcários sofreram recristalização intensa, adquirindo então cores claras, brancas e rosadas, ao lado de textura sacaróide. Em geral, a estrutura é xistosa, ainda que melhor perceptível em amostras intemperizadas, enquanto que a textura varia de granoblástica a nematoblástica.

Os componentes carbonáticos representam na maior parte das vezes mais de $90 \%$ de sua mineralogia, a despeito de existirem variedades portadoras de porcentagens elevadas de minerais micáceos e de quartzo. Calcita constitui o principal mineral carbonático. Comumente ela é pouco idiomórfica, ao lado de mostrar forte tendência ao alongamento na direção da xistosidade e geminar-se polissinteticamente. A sua granulação é ligeiramente superior à dos demais constituintes da rocha. Quartzo é também comum, ocorrendo disseminado irregularmente no interior dos calcários, ou concentrado em determinadas faixas de espessura milimétrica. É sempre xenomórfico, além de portador de extinção ondulante. A proporção dos minerais micáceos, muscovita (sericita) e flogopita, aparecendo raramente biotita e clorita, é variável, porém marcadamente maior nas amostras situadas junto às intercalações de filitos e micaxistos. Formam cristais placóides, isorientados na direção da xistosidade e imbricados aos grãos de quartzo. Nos calcários mais impuros, a sua porcentagem torna-se maior, imprimindo então às rochas típica textura lepidoblástica. Ocasionalmente, esses calcários são portadores de grande número de espécies minerais, tais como turmalina, plagioclásio, titanita, epídoto, rutilo, zircão e opacos diversos.

DOLOMITOS As rochas dolomíticas guardam em geral as mesmas características petrográficas das calcárias. São rochas de granulação fina, textura marcadamente granoblástico e cores claras, com a coloração variando de branco a cinza e, mais raramente, tendendo a tonalidades róseas.

A exemplo dos calcários, os dolomitos formam também camadas contínuas, orientadas lés-nordeste-oés-sudoeste, com espessura variando de algumas dezenas até centenas de metros. A maior delas constitui a ocorrência da Tapagem, extenso corpo de rochas dolomíticas altamente silicosas. Associam-se freqüentemente a metassedimentos arenosos e argilosos, originando então estrutura bandada, peculiar, e exibem feições morfológicas de dissolução indicativas de topografia cárstica. 
Sua mineralogia é caracterizada pela dominância de dolomita, o principal mineral carbonático, em adição a quartzo, talco, flogopita, titanita e opacos. Nas proximidades de corpos intrusivos, essas rochas adquirem, ao lado de feições texturais, novas associações paragenéticas, tendo piroxênios (diopsídio), anfibólios (tremolita), epídotos (clinozoisita) e granadas (grossulária) como principais componentes.

CALCOXISTOS Sob essa denominação, ou também de calcários xistosos, estão enquadrados todos os tipos transicionais envolvendo, de um lado, material carbonático e, de outro, metassedimentos argilo-arenosos. Em geral, formam corpos pequenos, de alguns metros a dezenas de metros de largura, em perfeita concordância com os metassedimentos adjacentes. Contudo são também encontrados na forma de enclaves, com dimensões chegando a atingir alguns quilômetros, no interior do maciço granítico Três Córregos, notadamente nas imediações de Cerro Azul. A espessura individual dos estratos é variável, de poucos milímetros a alguns metros, sendo sua seqüência aparentemente irregular. Exceção marcante é dada pelos metarritmitos que afloram na região do Calabouço, vale do Rio Palmital, poucos quilômetros ao sul da cidade de Apiaí ("gorotubitos", de Geoffrey e Souza Santos, 1942), cuja espessura parece alcançar centenas de metros. Do ponto de vista textural, os calcoxistos apresentam como traço constante a presença de um fabric granoblástico, passando por vezes a levemente nematoblástico em algumas amostras, junto aos leitos de natureza não-carbonática. Os estratos areno-argilosos, face à diversificação de sua composição mineralógica, ostentam textura granoblástica, causada pela presença dominante de quartzo; lepidoblástica, quando os constituintes micáceos abundam; ou mesmo nematoblástica, caso em que anfibólios representam os principais componentes. A granulação é variável, passando de finíssima (caso particular das calciossilicatadas do vale do Palmital) a média, por exemplo, em amostras situadas em alguns cortes da estrada Apiaí-Ribeira.

Mineralogicamente, os estratos carbonáticos compõem-se de calcita e dolomita, ocorrendo subordinadamente os mesmos constituintes acidentais comuns aos calcários e dolomitos da região. Já os leitos de composição original areno-argilosa são portadores de uma mineralogia mais diversificada, tendo sido identificados: quartzo, tremolita, actinolita, hornblenda, flogopita, plagioclásio, microclínio, dipsídio, epídoto, titanita, turmalina, escapolita e opacos.

Anfibolitos e anfibólioxistos Numerosas ocorrências de rochas anfibolíticas, formando na maior parte das vezes intercalações nos metassedimentos do Grupo Açunguı ou, então, associadas a corpos graníticos e mesmo rochas gnáissicas e migmatíticas, foram assinaladas na área investigada. Em geral, constituem corpos lenticulares de pequena espessura, não mapeáveis na escala adotada, concordantes com a estrutura regional, com um grande número de ocorrências confinado à região entre Guapiara e Apiaí. Ocorrências mapeáveis são raras, merecendo registro as localizadas nas imediações da represa, a noroeste de Eldorado, folha de Capão Bonito, possuindo $300 \mathrm{~m}$ de espessura, e na porção setentrional da folha de Cerro Azul, a sudoeste do lugarejo denominado Lagoinha, em associação com o maciço granítico Três Córregos.

São rochas escuras, pretas ou preto-esverdeadas, de granulação fina a média, e comumente portadoras de xistosidade. No campo, empregou-se o termo anfibolioxistos para melhor caracterizar as variedades fortemente xistosas, reservando-se a expressão anfibolitos para os tipos com textura tendendo ligeiramente a granoblástica, esses últimos mais abundantes. Às vezes, essas rochas apresentam alternância de leitos claros e escuros, portadores, respectivamente, de minerais siálicos e ferromagnesianos. 
Feições reliquiares, de grande importância no estabelecimento da gênese dessas rochas, são raramente encontradas, limitando-se apenas à presença de núcleos de piroxênios no interior de cristais de anfibólios. Como regra geral, pode-se afirmar que os anfibolitos da área mostram-se intensamente recristalizados a ponto de terem sido destruídas a maior parte das evidências indicativas de sua natureza original.

Feldspatos e anfibólios são seus principais minerais, representando na quase totalidade das amostras examinadas mais de $90 \%$ do seu volume. O feldspato é plagioclásio, de composição andesina, enquanto que o anfibólio corresponde a uma hornblenda verde comum. Raramente o plagioclásio mostra hábito ripiforme, ocorrendo na maioria das vezes na forma de grãos xenomórficos. Geminação polissintética tem sido reconhecida freqüentemente e, por vezes, aparecem geminações complexas do tipo albita-Carlsbad e albita-periclínio. Nos cristais geminados, as lamelas dos indivíduos são pouco nítidas, de contatos em geral difusos e sinuosos; a presença dos minerais de alteração, especialmente sericita, dificulta ainda mais a caracterização dos minerais. Por vezes, os plagioclásios estão fraturados, dotados de inclusões, e têm suas linhas de clivagem contorcidas face à ação dinâmica do processo metamórfico. Nessas condições, apresentam-se saussuritizados, dando origem a agregados heterogêneos constituídos dominantemente de minerais do grupo dos epídotos (clinozoisita e pistacita), ao lado de albita, calcita e sericita. Comumente, o anfibólio é uma hornblenda verde, todavia variedades castanhas também estão presentes, sobretudo nas amostras portadoras de clinopiroxênios.

Evidências de retrometamorfismo, traduzidas na formação de actinolita, fibrosa e incolor a verde claro, às expensas de hornblenda, e na saussuritização do plagioclásio, têm sido observadas em diversas amostras, mais particularmente nas provenientes dos pequenos corpos lenticulares.

Quartzo é o principal constituinte acidental dessas rochas, aparecendo seja na forma de grãos xenomórficos dispersos irregularmente no interior da massa cristalina, seja concentrado em cordões. Apatita é praticamente visível em todas as lâminas, o mesmo sucedendo com a titanita e os opacos, enquanto que clorita e calcita formam, ao lado dos minerais secundários anteriormente citados, os demais constituintes dos anfibolitos.

Gnaisses e migmatitos Essas rochas afloram continuamente na parte meridional da área desde a cidade de Jacupiranga até as adjacências do lugarejo Colônia Marques de Abrantes. Além disso, aparecem em núcleos no interior de metassedimentos de grau mais baixo, nas localidades de Anta Gorda e Tirivas, situadas pouco a leste e noroeste da Vila de Tunas, Paraná.

Trata-se de rochas com aspecto migmatítico, sendo possível distinguir, com base em evidências petrográficas, dois tipos principais de variedades afins: (a) migmatitos homogêneos (gnaisses leucocráticos), de bandeamento ausente, irregular ou difuso, freqüentemente granoblásticos, e portadores de espessas bandas quartzofeldspáticas, que se acham separadas por delgados leitos de biotita; e (b) migmatitos heterogêneos (gnaisses fitados), com bandeamento pronunciado, portadores de faixas paralelas ou subparalelas máficas e siálicas, de espessura geralmente centimétrica, e mostrando por vezes dobramentos ptigmáticos. Subordinadamente, são encontradas nas rochas migmatíticas algumas intercalações, com espessura atingindo ocasionalmente mais de um metro, de anfibolitos ou anfibolioxistos.

Mineralogicamente, as variedades litológicas diferem apenas quanto à proporção relativa dos seus principais constituintes. Feldspatos, microclínio e oligoclásio representam, ao lado do quartzo, os principais componentes siálicos. Por outro lado, biotita é o ferromagnesiano mais abundante, aparecendo subordinadamente hornblenda. 
Microclínio, seja na forma de cristais maiores, seja na condição de integrante da matriz, apresenta-se quase sempre geminado em grade, além de exibir freqüentes indícios de pertitização. O plagioclásio ocorre em geral disperso no interior do agregado siálico granoblástico. Comumente mostra-se geminado segundo a lei da albita e, em menor extensão, de acordo com a lei do periclínio. Por vezes, altera-se em minerais do grupo do epídoto (clinozoisita e pistacita) ou mesmo em sericita. Os intercrescimentos pertíticos, antipertíticos e mirmequíticos são relativamente comuns. $\mathrm{O}$ quartzo é xenomórfico, além de portador de extinção ondulante na maior parte das amostras examinadas.

Nas variedades homogêneas, os minerais ferromagnesianos formam delgadas linhas irregulares, enquanto que, nas heterogêneas, eles imprimem às rochas uma textura fortemente orientada, seja de caráter lepidoblástico, quando então biotita é o máfico mais importante, seja de caráter nematoblástico, caso da hornblenda.

Associados às faixas escuras, nota-se também a presença de titanita, epídotos, opacos e, ocasionalmente, piroxênios. Estes, pertencentes ao grupo augita-diopsídio, relacionam-se intimamente aos anfibólios, que se formaram às suas expensas, como sugerem as feições texturais. Em algumas amostras observou-se ainda que, em lugar da hornblenda comum, ocorre actinolita, de coloração verde-clara e forma fibrosa. Apatita e zircão foram também reconhecidos na condição de minerais acessórios.

As rochas gnáissicas das localidades de Anta Gorda e Tirivas diferem um pouco das variedades já descritas.

Trata-se de gnaisses de granulação variada, levemente bandados, portadores de porfiroblastos de feldspato alcalino, que lhes atribuem típica estrutura facoidal. Os fenoblastos, de dimensões centimétricas, possuem forma lenticular e coloração variável entre rósea e avermelhada. $\mathrm{O}$ bandeamento, mais proeminente nas variedades de granulação mais fina, acha-se evidenciado pela alternância de leitos claros, com textura marcadamente granoblástica, e escuros, com fabric dominantemente lipidoblástico e, em menor proporção, nematoblástico, face à natureza do mineral ferromagnesiano. A espessura das bandas é variável, mantendo-se geralmente em torno de alguns centímetros. A totalidade das amostras investigadas exibe feições indicativas de forte deformação, traduzidas no estiramento de minerais, extinção ondulante, encurvamento de linhas de clivagem e geminação etc., seguida de recristalização.

A mineralogia é relativamente simples e semelhante à das variedades já descritas. A proporção siálicos: máficos é variável, reconhecendo-se assim variedades leucocráticas e mesocráticas. Ebert et al. (1971, p. 185) mencionam a presença de andaluzita e cordierita nessas rochas, que atribuem à ação de metamorfismo de contato.

Geologia e petrografia das rochas graníticas Numerosos corpos graníticos recortam a área mapeada, com maior destaque, face a maior extensão, para os batólitos Três Córregos e satélites, Agudos Grandes, Itapeúna e Cunhaporanga. Esse último, a despeito de ocupar pequena superfície na carta, estende-se para sudoeste, no Estado do Paraná, cobrindo então uma área total superior a $2000 \mathrm{~km}^{2}$ (Fuck et al., 1967). Além desses corpos maiores, foram também mapeados alguns maciços de dimensões intermediárias, correspondendo aos do Guaraú, Espírito Santo, Morro Grande, Aboboral, Itaoca, Mandira e Alto Turvo, bem como outros menores, constituindo pequenos stocks, ocorrências de Varginha, Freguesia Velha, Barreiro, Rolado, Vila Branca, Epitácio Pessoa, Capuava, Apiaí e Campina do Veado. Finalmente, devem ser mencionadas as ocorrências de granitos pórfiros, que, em razão de suas características próprias, serão abordados isoladamente ao final do capítulo. 
Os maciços graníticos apresentam características comuns de tardi- ou pós-tectônicos, representando corpos circunscritos de forma ovalada. Somente o granito de Itapeúna possui caracteres nitidamente diferentes, pois os seus contatos exibem nítida gradação para os metassedimentos regionais e seus constituintes minerais apresentam-se alinhados e configurando certo bandeamento. Esses fatos levam a acreditar numa origem sintectônica para esse último complexo.

No tocante à composição, a maior parte deles pertence à categoria dos chamados calco-alcalinos, com exceção dos maciços do Guaraú, Mandira e, eventualmente, Alto Turvo, que possuem, pelo menos em alguns trechos, nítida tendência alcalina.

Com base em caracteres petrográficos, é possível dividir preliminarmente os corpos graníticos em três categorias: (a) tipo porfiróide, cujo principal representante na área é o Três Córregos; (b) tipo migmatítico, tendo o granito Itapeúna como único representante; e (c) tipo equigranular, cujos principais representantes são os maciços do Guaraú, Mandira e Alto Turvo.

No entanto deve ser enfatizado que, em qualquer dos complexos graníticos em exame, aparecem diferentes variedades petrográficas, quanto à composição mineralógica e textural, de modo que os maciços são classificados, em qualquer das três categorias, de acordo com o tipo petrográfico mais comum que eles apresentam. Entretanto, variações entre os diversos tipos petrográficos são freqüentes e transicionais em cada complexo.

Tipo porfiróide Os maciços pertencentes a esse grupo ocupam a maior parte da área coberta pelas rochas graníticas. Distribuem-se por toda a área mapeada, conquanto que a sua maior concentração esteja ligada a uma faixa, orientada nordeste-sudoeste, que corta diagonalmente a região. Trata-se dos complexos graníticos Três Córregos, Agudos Grandes, Gunhaporanga, Itaoca, Espírito Santo, Morro Grande, Aboboral etc. Em geral essas rochas graníticas formam as principais serras da região, como Itapirapuã, Lanhoso, Gorutuba, Agudos Grandes etc.

$\mathrm{Na}$ sua quase totalidade, esses corpos possuem forma ovalada pronunciadamente alongada para nordeste-sudoeste, e suas bordas são em geral nítidas e precisas. Os contatos podem ser considerados, a grosso modo, concordantes com as encaixantes regionais, a despeito de apresentarem localmente características discordantes. Em certos locais da zona de contato de alguns desses maciços, as rochas graníticas adquirem estruturas bandeadas, traduzidas na alternância de faixas enriquecidas em constituintes siálicos e máficos, ao lado de outros caracteres comuns a migmatitos heterogêneos, como foliação e dobramento ptigmáticos. Tais feições, aliadas à presença de zonas de brechação e mesmo milonitização, parecem indicativas de uma fase ativa de tectônica de borda ligada à formação do maciço. O caráter intrusivo de alguns desses corpos acha-se evidenciado pela existência de auréolas de metamorfismo de contato, ao lado da ocorrência de numerosas apófises graníticas, filões aplíticos e pegmatíticos, e intrusões de granitos pórfiros cortando os metassedimentos regionais. No tocante à ação de contato, poder-se-iam citar, por exemplo, as ocorrências relacionadas ao granito Três Córregos que se situam nas circunvizinhanças de Socavão e Gerro Azul, bem como as ligadas ao granito Itaoca, em particular nas proximidades da mina de Panelas, essas últimas amplamente discutidas por Melcher (1968).

A principal feição desses granitos porfiróides consiste em sua textura, onde os cristais maiores de microclínio, de coloração variável de branca a rósea, possuem dimensões médias da ordem de 1-2 cm. A matriz exibe granulação milimétrica e coloração tendendo a cinzento-clara. Ao microscópio, a textura apresenta caráter tipicamente hipidiomórfico granular. Os cristais maiores ostentam em geral formas próprias e, por vezes, estrutura poiquilítica, tendo biotita, feldspato e quartzo como inclusões mais comuns. Macroscopi- 
camente, é possível reconhecer-se geminação Carlsbad na quase totalidade dos cristais. Nas regiões de contato de alguns desses maciços, os cristais maiores, assim como outros constituintes minerais (biotita e hornblenda), encontram-se alinhados, imprimindo então às rochas lineação pronunciada.

Quanto à composição mineralógica, verifica-se que feldspatos (microclínio e plagioclásio), quartzo, biotita e hornblenda são os constituintes principais, aparecendo titanita, apatita e opacos como acessórios. Sericita, epídoto, clorita e carbonatos formam os produtos de alteração mais comuns. A proporção feldspato alcalino: plagioclásio não é constante, levando conseqüentemente à formação de rochas com composição variável desde granito até granodiorito. Aparentemente, granito e adamellito constituem as variedades mais comuns.

Microclínio, freqüentemente geminado em grade, é o principal representante do grupo dos feldspatos alcalinos. Ocorre, seja na forma de cristais isolados, seja intercrescido com albita, originando então estruturas do tipo pertítico. O plagioclásio, em geral geminado polissinteticamente e por vezes portador de zoneamento normal, tem sua composição situada no campo do oligoclásio. Mais raramente associa-se ao quartzo, formando estruturas mirmequíticas. Mostra visível tendência ao idiomorfismo e, dentro do grupo dos siálicos, é o primeiro mineral a se cristalizar. Quando cristalizado isoladamente, o quartzo é sempre xenomórfico, além de comumente apresentar-se fraturado, com extinção ondulante e textura em mosaico. Biotita, de coloração castanha e pleocroísmo acentuado, é o ferromagnesiano mais abundante, aparecendo subordinadamente hornblenda verde comum. Esses minerais alteram-se em clorita, principalmente ao longo das bordas e direções de clivagem dos cristais. Pistacita e clinozoisita associam-se intimamente ao plagioclásio e, em menor proporção, à hornblenda, exibindo nítidos indícios de terem se formado às suas expensas.

Sericitização é a transformação mais comum dos feldspatos alcalinos, sendo também observada nos plagioclásios. Em adição à titanita, apatita e opacos, zircão e allanita têm sido também identificados com acessórios, na forma de pequenas inclusões em minerais ferromagnesianos, principalmente biotita.

Tipo migmatítico Como referido previamente, esse grupo tem como representante único na área mapeada o granito de Itapeúna. Esse corpo, localizado na porção este-sudoeste do mapa, folha de Eldorado, possui forma irregular, alongada para lés-nordeste, concordante com a estrutura regional, e se estende nessa direção por uma distância aproximada de $50 \mathrm{~km}$. Constitui o acidente geográfico mais importante da região de Eldorado, correspondendo às serras denominadas de Jaguari, Hilário e Bananal Pequeno. Sua largura é variável, passando de uma dimensão mínima de uns poucos quilômetros, na extremidade sul do corpo, a um valor máximo de 10 , na sua região central. Â exceção de pequenas áreas nas bordas norte e sul, respectivamente, em contato com as rochas carbonáticas da Tapagem e as alcalinas do distrito de Jacupiranga, o restante do maciço encontra-se associado a metassedimentos pelíticos do Grupo Açungui.

Em diversos pontos da zona de contato desse complexo, notou-se passagem gradacional das rochas graníticas para os metassedimentos regionais. Observou-se também, sobretudo nas partes marginais do corpo, orientação pronunciada dos seus contituintes minerais ligada a processos ativos de deformação plástica, com as rochas graníticas assumindo então aspecto de verdadeiros migmatitos.

Quanto à textura, verifica-se que esta varia de porfiróide, com cristais maiores de feldspato alcalino, a equigranular. Em grande parte da área ocupada, as amostras exibem forte orientação. 
A mineralogia é simples e os tipos petrográficos situam-se entre graníticos e adamellíticos, face à proporção variável dos feldspatos alcalinos e plagioclásios. A variedade alcalina é microclínio, com típica geminação em grade e incipiente alteração em sericita, enquanto que o plagioclásio corresponde a um oligoclásio. Quartzo e biotita formam os demais componentes essenciais, aparecendo apatita, titanita, allanita e opacos como os acessórios mais comuns. Em adição à sericita, aparecem também clorita e epídoto, derivados, respectivamente, de biotita e plagioclásio.

Tipo equigranular Os maciços do Guaraú, Mandira e, eventualmente, Alto Turvo constituem os representantes desse grupo. Geograficamente acham-se confinados à região sul-sudeste da área, concentrando-se quase que inteiramente na folha de Eldorado. Excelentes exposições das rochas graníticas do Guaraú e Alto Turvo são encontradas ao longo da estrada federal BR-116, enquanto que os melhores afloramentos do maciço Mandira confinam-se à estrada Jacupiranga-Cananéia. Os maciços Guaraú e Mandira constituem os principais acidentes geográficos da porção meridional da folha de Eldorado, correspondendo ao primeiro o conjunto das serras do Guaraú, Azeite, Braço Feio, Cardoso, Anta Gorda e Cadeado, e ao segundo, o conjunto das serras do Mandira e Itapitangui. Enquanto que os granitos do Alto Turvo e Mandira acham-se circundados inteiramente por gnaisses e migmatitos, as rochas do Guaraú associam-se quer a migmatitos, quer aos micaxistos regionais.

Esses granitos diferem dos demais complexos da região pelo caráter essencialmente equigranular de sua textura. São rochas de granulação média a grossa, de coloração clara, tendendo sempre a tonalidades róseas, e portadoras ao microscópio de textura hipidiomórfica granular.

Uma de suas principais características petrográficas reside na aparente constância de sua composição granítica, onde feldspatos alcalinos, representados .por um ortoclásio pertítico comumente geminado segundo a lei de Carlsbad e por vezes portador de inclusões de plagioclásio, estão invariavelmente presentes em maior proporção que os plagioclásios. Quartzo e plagioclásio (oligoclásio), em geral geminado polissinteticamente, completam o grupo dos félsicos, enquanto que biotita constitui o ferromagnesiano mais comum, aparecendo subordinadamente hornblenda. Acidentalmente, tais rochas contêm anfibólios sódicos (riebeckita e ferro-hastingsita), ainda que em pequenas proporções, fato que lhes confere típico caráter alcalino. Nessas variedades, o plagioclásio é mais sódico. Fluorita, opacos, zircão, allanita, titanita e apatita são os acessórios mais freqüentes, ocorrendo clorita, sericita, epídoto e carbonatos como principais produtos de alteração.

Essas rochas guardam semelhanças mineralógicas e texturais com os granitos alcalinos dos maciços Anhangava e Graciosa, Estado do Paraná, que foram objeto de inveștigação por Cordani e Girardi (1967) e Girardi (1969).

Granitos pórfiros Diversas ocorrências de granitos pórfiros foram assinaladas na área estudada. Na maior parte das vezes, trata-se de diques, não mapeáveis na escala adotada, de espessura variável, raramente ultrapassando alguns poucos metros. Contudo também são vistos formando pequenos stocks, com área de exposição de algumas centenas de metros quadrados. No primeiro caso, enquadram-se as ocorrências de Morro Azul, distante 10 km da localidade de Ouro Verde, folha de Itararé, Sítio da Serra, na quadrícula de Capão Bonito, e proximidades dos marcos 253-255 km da estrada federal BR-116 (São Paulo-Curitiba), na folha de Eldorado, enquanto que ao segundo pertencem as ocorrências mais conhecidas, objeto inclusive de referências na literatura geológica. Dentre elas, merecem menção os corpos do Lageado (Bastian, 1946), Braço da Pescaria (Barbosa e 
Passos Guimarães, 1946), bem como os de Lumbria, do vale do Rio Turvo, nas adjacências da barra do Rio Barreiro, e do vale do Rio Guaraú.

No campo, os granitos pórfiros encontram-se intrusivos nos metassedimentos do Grupo Açungui, ou nos corpos graníticos, ou mesmo nos migmatitos. A julgar pela associação geográfica, essas ocorrências poderiam estar geneticamente relacionadas às inúmeras intrusões graníticas que recortam a área.

Trata-se de rochas duras e compactas que, quando não alteradas, exibem comumente coloração cinzento-clara. Macroscopicamente, é possível reconhecer-se a presença de uma textura inequigranular, porfirítica ou glomeroporfirítica, onde fenocristais de dimensões variáveis entre $0,3 \mathrm{~mm}$ e $1,5 \mathrm{~cm}$ ocorrem dispersos em massa fundamental afanítica, de granulação raramente excedendo a $0,05 \mathrm{~mm}$. Os fenocristais possuem formas próprias e estão representados principalmente por quartzo e feldspatos e, em menor proporção, por biotita, clorita e titanita. Ocasionalmente, tais rochas são portadoras de estrutura fluidal, causada pela isorientação dos fenocristais.

Em algumas lâminas delgadas, observa-se a presença de cristais de quartzo exibindo formas de bipirâmide hexagonal, combinadas por vezes com faces prismáticas. Em geral, essas últimas são muito curtas e acentuadamente menores que as primeiras. A forma desses cristais parece indicativa de que, ao tempo de formação da rocha, o mineral era estruturalmente quartzo beta. Indícios de corrosão magmática são encontrados em vários desses fenocristais. Feldspato alcalino e plagioclásio, de composição oligoclásio, formam com o quartzo os minerais dominantes da rocha, ocupando em geral mais de $95 \%$ do seu volume. O feldspato alcalino acha-se representado por microclínio, que, em algumas lâminas, mostra características ópticas mựto mal definidas, traduzidas principalmente na irregularidade ou mesmo ausência de geminação gradeada típica, levando à suposição de que o mineral tenha sido originalmente de outra natureza (ortoclásio?), mais compatível com a temperatura elevada reinante ao tempo de formação da rocha. A massa fundamental contém, ao lado dos constituintes siálicos, biotita e subordinadamente minerais acessórios (titanita, apatita e opacos) e de alteração. Estes últimos estão representados por clorita e sericita, derivados respectivamente da biotita e plagioclásio e, em menor escala, por carbonatos.

Metamorfismo Com exceção da parte meridional da área, as condições de metamorfismo regional exibidas pelas litologias que integram o Grupo Açungui parecem corresponder à fácies dos xistos verdes de Turner (1968). Em alguns afloramentos, em especial os situados nos cortes da estrada Apiaí-Iporanga, ainda são visíveis feições estruturais e texturais dos antigos sedimentos que originaram as parametamórficas do grupo que, dado o caráter relativamente brando do metamorfismo que as atingiu, mostram-se preservadas. Assim, ainda é possível reconhecerem-se - vestígios de antigas estruturas sedimentares, como marcas de ondas, estratificação cruzada e gradacional, estruturas originadas por fósseis etc., assim como traços texturais, sobretudo em metassedimentos arenosos, comuns às rochas sedimentares, como presença de material cimentante, seleção e arredondamento dos grãos etc. Esses fatos apontam o caráter incipiente dos processos de recristalização atuantes sobre tais rochas.

As associações mineralógicas presentes nos metassedimentos argilosos, refletidas na presença constante dos minerais micáceos muscovita e clorita, e, mais raramente, biotita, ao lado da granulação fina dessas rochas, que impede o reconhecimento macroscópico de seus constituintes minerais, constituem também evidências indicativas da natureza epizonal do processo metamórfico regional. 
Nas várias unidades litológicas aflorando na região assinalada, caracterizada por metamorfismo epizonal, as paragêneses mais freqüentes são constituídas por: (a) seqüência areno-argilosa: quartzo, quartzo-muscovita, quartzo-muscovita-clorita; (b) seqüência carbonática: carbonatos-quartzo, carbonatos-quartzo-muscovita, carbonatos-muscovita; (c) seqüência básica: actinolita-albita-epídoto.

Contudo é possível constatar-se que o gradiente metamórfico da região cresce no sentido geral de noroeste para sudeste, como já observado por Melfi et al. (1965). Por exemplo, na seqüência aluminosa, ao lado de xistosidade mais pronunciada e granulação mais grosseira das rochas, aparecem, na parte sudeste da área, paragêneses indicativas de maior grau de metamorfismo. Tem lugar então o desenvolvimento de minerais como biotita, granada, estaurolita e cianita junto aos xistos regionais que afloram ao longo dos vales dos rios Pardo, São Sebastião e do Ribeirão Grande. Na primeira das seções mencionadas, é perfeitamente possível acompanhar-se a transformação gradativa dos termos mais filíticos da seqüência, mais abundantes nas imediações de Iporanga, em micaxistos, nas proximidades de Barra do Turvo. Mais para o sul, subindo os vales dos rios Pardo e Turvo, os micaxisıus são vistus passar de forma aparentamente contínua a gnaisses e migmatitos. Essas mudanças mineralógicas e texturais devem refletir diferentes condições metamórficas, marcadas por um aumento progressivo do gradiente rumo sudeste. A julgar pelas associações mineralógicas reconhecidas, esses metassedimentos poderiam ter-se formado em condições compatíveis com a fácies de transição xistos verdes-anfibolito, ou mesmo anfibolito para as últimas rochas, usando-se a nova classificação proposta por Turner (1968).

Por outro lado, os metabasitos da área, tendo anfibolitos e mais raramente anfibólioxistos como principais representantes, são quase que invariavelmente portadores de paragêneses condizentes com a fácies anfibolito.

As associações mineralógicas, refletindo as novas condiões de metamorfismo de fácies anfibolito, são assim representadas: (a) seqüência areno-argilosa: quartzo-biotita (granada-estaurolita), quartzo-feldspato biotita (hornblenda), com o feldspato correspondendo às variedades microclínio e um plagioclásio de composição oligoclásio; (b) seqüência básica: hornblenda-andesina.

Em superposição ao processo dinamotermal regional, os metassedimentos do Grupo Açungui viram-se atingidos localmente por eventos metamórficos adicionais, causados pelas várias intrusões graníticas que recortam a área. Evidências indicativas de metamorfismo termal e/ou contato são encontradas, por exemplo, junto aos complexos Três Córregos, Itaóca, Espírito Santo e Morro Grande. Nas rochas da seqüência areno-argilosa, foram observadas modificações texturais, traduzidas na recristalização dos cristais, e na formação de novos minerais. Contudo são as encaixantes carbonáticas que, em razão de sua maior susceptibilidade às variações químicas, exibem associações mineralógicas características e capazes de fornecerem idéia mais concreta quanto à intensidade do processo. Feições evidenciando metamorfismo de contato têm sido reconhecidas, seja quando essas rochas ocorrem na forma de enclaves nos corpos graníticos, seja quando integram as seqüências metassedimentares.

As várias associações mineralógicas exibidas localmente pelo metassedimento do Grupo Açungui nas regiões de contato com as intrusivas graníticas possibilitam o enquadramento das rochas nas fácies de contato albita-epídoto hornfels, hornblenda hornfels e piroxênio hornfels de Turner (1968).

Rochas pertencentes à primeira fácies foram encontradas em vários locais da região de contato dos granitos Três Córregos e Morro Grande (Marini et al., 1967). Segundo esses autores, a paragênese mais comum nos filitos afetados pelo metamorfismo de contato 
é constituída de quartzo-muscovita-biotita (epídoto). Filitos com andaluzita, que também podem ser enquadrados nessa fácies, afloram junto à região de contato da extremidade sul do granito do Espírito Santo.

Associações mineralógicas condizentes com a fácies hornblenda hornfels foram observadas em vários lugares da área, principalmente junto às auréolas de contato dos granitos Três Córregos e Itaoca. Marini et al. (1967), por exemplo, mencionam a existência de rochas carbonáticas, caracterizadas pela paragênese hornblenda-plagioclásio, aflorando nas imediações de Cerro Azul, Paraná. Por outro lado, Melcher (1968) cita a ocorrência de verdadeiros escarnitos junto às localidades de Serrinha, Porto de Apiaí e Panelas, como resultado da ação de contato do granito Itaoca. As rochas que afloram na área da mina de Panelas, proximidades do aeroporto, são portadoras de uma mineralogia rica em silicatos de cálcio e magnésio, tendo sido reconhecidas as seguintes associações paragenéticas: quartzo-diopsídio-hornblenda (microclínio), carbonatos-diopsídio e carbonatos-flogopita. Ao lado desses minerais, porém com ocorrência muito mais restrita, foram identificados plagioclásio cálcico, vesuvianita e prenhita.

Segundo Marini et al., (1967), condições metamórficas compatíveis com a fácies piroxênio hornfels foram atingidas por escarnitos que afloram na forma de pequenos roof pendants junto ao granito Três Córregos, a $1 \mathrm{~km}$ da cidade de Cerro Azul, Paraná, na rodovia Curitiba-Cerro Azul. Nessas rochas, a paragênese é a seguinte: diopsídio-wollastonita-plagioclásio.

Diversas rochas da região exibem feições mineralógicas e texturais indicativas de terem sido submetidas a processos de natureza retrometamórfica. Tais processos, de ação confinada a zonas de movimentação, e de idade posterior aos demais, parece terem atingido indistintamente as diversas litologias da área, conquanto seus efeitos sejam melhor perceptíveis junto aos metabasitos, com a associação mineralógica actinolita-albita-epídoto denunciando a existência de desequilíbrio metamórfico.

Estruturas As rochas metamórficas que ocorrem na região do Ribeira exibem invariavelmente orientação pronunciada. Na maioria dos casos, a estrutura predominante é a xistosidade, formada pelo alinhamento de minerais placóides (clorita, muscovita e biotita) e prismáticos (anfibólio), ou pela isorientação de fraturas e microfraturas geradas por cizalhamento. Clivagem tectônica, de origem semelhante a esse último tipo de xistosidade, é também observada em algumas rochas de caráter ardosiano que afloram nas imediações de Itapeva, a norte de Campina do Veado.

Nos metassedimentos atingidos pelo metamorfismo de baixo grau, e, em particular, nos que afloram nas folhas de Capão Bonito, Guapiara e região setentrional da quadrícula de Apiaí, planos de acamamento ainda podem ser reconhecidos através da alternância de leitos, cuja espessura em geral é centimétrica a decimétrica, e cuja constituição variável muito provavelmente corresponde às diferenças primárias de composição dos sedimentos. Outras estruturas sedimentares, tais como marcas de onda ou estratificações cruzadas, também podem, eventualmente, ser reconhecidas. Nas rochas argilosas, diferenças de constituição entre as diversas camadas são de difícil caracterização, porém o acamamento ainda pode ser distinguido pela alternância de leitos de diferentes cores. Nas rochas arenosas, a estratificação é reconhecida pela presença de leitos micáceos originalmente de composição argilosa, enquanto que nos metassedimentos carbonáticos o acamamento é representado por delgadas intercalações arenosas e argilosas. De maneira geral, a xistosidade desenvolveu-se concordantemente ao acamamento e em algumas exposições, em especial de metassedimentos pelíticos, pode ser observado que ela é nitidamente transversal à estratificação, o que parece indicar a existência de dobras do tipo fechado. 
Os planos de xistosidade e/ou acamamento original apresentam direção geral nordeste-sudoeste e seus mergulhos são variáveis, quase sempre para noroeste. No entanto tais direções podem sofrer deflexões locais, inclusive nas rochas gnáissicas e migmatíticas, passando, por exemplo, a noroeste-sudeste, como acontece nas adjacências da Usina da Pasta, folha de Cerro Azul, ou para leste-oeste, na área situada a sudeste da localidade de Barra do Turvo.

Os processos tectônicos produziram dobramentos em diferentes escalas além de numerosos falhamentos. Como resultado de variações na competência, as variedades litológicas da área apresentam características tectônicas diferentes. Os metassedimentos argilosos, mais plásticos, exibem dobramentos fechados, desde pequenos corrugamentos microscópicos até dobras de amplitude quilométrica. Rochas carbonáticas, quando silicosas, apresentam dobramentos mais suaves muitas vezes simétricos, com fracos mergulhos de seus flancos. Nas rochas quartzíticas, parece dominar um estilo tectônico mais rígido, ocorrendo intenso fraturamento, embora as variedades mais ricas em minerais micáceos também exibam dobramentos, simultaneamente.

Lineação é uma feição conspícua das rochas metamórficas. Foi reconhecida, em muitos afloramentos, representando estrias de fricção em planos de cisalhamento, ou, então, direção dos eixos de dobramento regionais. Para o segundo caso, quando então representa elemento decisivo na interpretação estrutural, observou-se que sua direção é dominantemente nordeste-sudoeste, acompanhando a xistosidade e seu caimento é em geral de poucos graus, com rumo tanto para sudoeste como para nordeste. Importante exceção ao quadro geral, é fornecida pelos migmatitos que afloram a leste-oeste da localidade Cajati, folha de Eldorado, ao longo da rodovia BR-116. Nessa área, a lineação, muito pronunciada, exibe caimentos de $10-30^{\circ}$ rumo sudeste, conquanto valores mais altos, até $50^{\circ}$, tenham sido também registrados.

A análise das estruturas dobradas da região é extremamente dificultada pelos falhamentos simultâneos e posteriores aos esforços de compressão, e pelas importantes intrusões graníticas. Resultou um padrão em blocos que mantêm uma orientação geral nordeste-sudoeste, mas cujas inter-relações são complexas, impedindo o reconhecimento das estruturas dobradas.

Os autores acreditam que, de um modo geral, as grandes intrusões graníticas marcam as posições dos principais anticlinórios, que acompanhariam, portanto, os complexos graníticos de Cunhaporanga, Três Córregos e Agudos Grandes. Um anticlinório adicional acompanharia as intrusões do Espírito Santo e Itaoca, e a estrutura das localidades de Tirivas e Anta Gorda. Estruturas em anticlinal foram assinaladas, por exemplo, na extremidade sul do mapa, junto às últimas localidades citadas. Constituem as anticlinais desventradas do Ribeirão da Barra e Anta Gorda, e foram objeto de citação por Marini et al. (1967). Possuem eixos orientados na direção nordeste-sudoeste e estão sublinhadas por quartzitos associados a gnaisses ocelares, contendo ocasionalmente itercalações de quartzitos micáceos e micaxistos. Pelo padrão de afloramentos, em decorrência de hipótese formulada pouco antes, as rochas metassedimentares aflorariam em grandes sinclinórios, rodeados e invadidos por intrusivas graníticas. Por exemplo, um sinclinório assimétrico, de direção N20-40E, aparece entre os complexos graníticos de Cunhaporanga e Três Córregos, atravessando diagonalmente a quadrícula de Itararé, com extensão de algumas dezenas de quilometros. Nessa estrutura, as camadas exibem mergulhos suaves, para sudeste do lado ocidental, sendo comum encontrarem-se camadas invertidas do lado oriental, com mergulhos também para sudeste. Nessa área, verifica-se que o caimento geral das dobras para nordeste faz com que estruturas sinclinais formem "narizes" voltados para sudoeste, enquanto que as estruturas anticlinais formam-nos voltados para o sul. Na região entre 
Pinhalzinho e Lagoinha, parece que as duas serras quartzíticas subparalelas constituem núcleos de anticlinais, separados por metassedimentos finos estratigraficamente superiores. A serra quartzítica oriental, em contato com o batólito granítico, constituiria afloramento da mesma camada que formou as duas camadas citadas anteriormente. Enorme falha, subparalela à direção das camadas, foi verificada na parte ocidental da serra quartzítica. Tal falha é provavelmente de empurrão, correspondente ao acavalamento do bloco sudeste sobre o bloco noroeste, como parecem indicar as atitudes das camadas.

Outras estruturas do tipo sinclinório, com eixos dirigidos para nordeste-sudoeste, parecem ocorrer a nordeste da localidade do Paqueiro, imediações do vale do Ribeirão Carumbê e proximidades da cidade de Ribeira, bem como nas adjacências da Tapagem, a nordeste da vila de Barra do Turvo.

A análise estrutural da porção central e oriental da área global mapeada é mais difícil do que a da folha de Itararé. Entretanto a vasta região entre os complexos de Três Córregos e Agudos Grandes, a qual inclui o provável anticlinório segundo o eixo Tirivas-Anta Gorda-Itaoca-Espírito Santo, deve corresponder a um (ou vários) grande(s) sinclinório(s) visto que parece abrigar predominantemente rochas das Formações Votuverava e Água Clara, as formações estratigraficamente superiores do Grupo Açungui.

Com relação às rochas gnáissicas e migmatíticas, que ocupam a parte sul-oriental do mapa, pouco é possível afirmar-se quanto à posição estrutural das unidades, visto que os processos petrogenéticos envolvidos na formação das rochas, em ambiente mesozonal, obliterou, em grande parte, as estruturas existentes anteriormente. Acresce que ainda não há elementos suficientes para enquadrar definitivamente tais rochas como contemporâneas às formações epizonais do Grupo Açungui, ou como representantes de seu embasamento.

As rochas da Ribeira foram submetidas a intensa perturbação tectônica, em grande parte contemporânea aos dobramentos e ao metamorfismo que afetaram os antigos sedimentos. No entanto, muitas dessas zonas de fraqueza foram reativadas em épocas posteriores, pois alguns falhamentos chegam a afetar os sedimentos devonianos e/ou permocarboníferos.

De maneira geral, as falhas principais que afetaram a área são aparentemente, do tipo empurrão, e acompanham a xistosidade de direção nordeste-sudoeste. Subordinadamente, aparece um sistema de grandes fraturamentos dirigido para noroeste-sudeste, provavelmente ligado à reativação tectônica mencionada, e incluindo essencialmente falhamentos normais, de gravidade. Outras direções, ainda que pouco desenvolvidas, foram também registradas.

Alguns dos maiores falhamentos atingem extensões consideráveis, sendo prontamente evidenciados nas fotografias aéreas por nítidos alinhamentos retilíneos. Um dos exemplos mais característicos consiste no falhamento da Serra do Paranapiacaba, que se estende entre as localidades de Vila Branca e Campina do Veado.

Ao sistema de fraturas com direção noroeste-sudeste, associa-se a intrusão de diques de diabásio mesozóicos. O vulcanismo basáltico constitui importante feição estrutural no Brasil meridional, e acha-se também representado na área, mostrando uma zona de maior concentração de diques paralelos nas imediações da cidade de Guapiara.

Os corpos graníticos apresentam formas alongadas em alinhamento regional paralelo às grandes estruturas metassedimentares. Entretanto essas rochas, excluído o maciço de Itapeúna, não evidenciam deformações plásticas expressivas, exceto ocasionalmente o alinhamento dos constituintes nas bordas dos corpos, com as litologias adquirindo então estrutura gnáissica. Em outros trechos, os granitos demonstram terem sido submetidos a esforços tectônicos posteriores à fase principal de sua intrusão, como evidenciado por estruturas cataclásticas ou mesmo miloníticas. De maneira geral, os contatos são concor- 
dantes com a direção das estruturas regionais, a despeito do grande número de ocorrências apontando relações discordantes. Cabe assinalar que, nos muitos casos em que foi possível a observação dos contatos entre os granitos e os metassedimentos, estes eram do tipo tectônico (falhamento), e não do tipo intrusivo normal.

Considerações sobre a evolução geológica regional A região do vale do Ribeira situa-se no interior de um dos cinturões orogênicos pertencentes ao Ciclo Brasiliano, que se desenvolveu no final do Pré-Cambriano e início do Eo-Paleozóico. Trata-se do cinturão orogênico Ribeira, cujo nome deriva justamente da região em apreço, e foi proposto por Almeida et al. (no prelo) em substituição à denominação vigente anteriormente, "Paraíba", visto que as rochas da Formação Paraíba s.s. revelaram-se na verdade mais antigas do que os eventos do Ciclo Brasiliano (Delhal et al., 1969; Cordani et al., 1973). O cinturão orogênico Ribeira estende-se ao longo da costa oriental brasileira, desde o sul da Bahia, e alcança a extremidade sul-oriental da República vizinha do Uruguai. Nessa unidade geotectônica aparecem rochas formadas em geossinclinais durante o Ciclo Brasiliano, ao lado de rochas pertencentes ao seu embasamento, mas que foram submetidas às mesmas condições tecto-orogênicas, durante o final do Pré-Cambriano e início do Paleozóico.

Os metassedimentos epizonais que constituem o Grupo Açungui são os que melhor representam o material depositado em ambiente geossinclinal, que sofreu a orogênese Brasiliana. As descrições efetuadas nos capítulos anteriores deste trabalho permitem caracterizar tal material como tendo sido depositado em ambiente original de sedimentação próximo da antiga linha de costa, em águas pouco profundas (Petri e Suguio, 1969). Esses autores estudaram principalmente as estruturas sedimentares das partes central e setentrional da região, e chegam a concluir que o Grupo Açungui, na região estudada, teria sido formado essencialmente em ambiente de plataforma continental, com o material provindo de área continental situada para noroeste. Eles chegam a caracterizar como de origem em ambiente continental alguns metassedimentos situados entre Itapeva e Ribeirão Branco, área onde estaria localizada a antiga linha de costa. Assim sendo, é possível que as espessuras estimadas por Marini et al. (1967) para as formações do Grupo Açungui possam ser, na verdade, um tanto exageradas. É plausível que o tectonismo intenso de compressão, traduzido por dobramentos isoclinais e por falhamentos de empurrão, tenha produzido um forte espessamento das seqüências metassedimentares levando a espessuras aparentemente maiores.

A seqüência metamórfica apresenta uma polaridade nítida, com aumento do grau de metamorfismo de noroeste para sudeste, de modo que o eixo da unidade geotectônica deve situar-se nessa ultima direção. Como já foi mencionado no item respectivo, parte das rochas gnáissicas e migmatíticas que ocorrem na parte sudeste da região representam material equivalente aos metassedimentos epizonais, enquanto que a parte restante representa a infra-estrutura da unidade geotectônica, exposta em núcleos de geoanticlinais. De qualquer modo, nos casos em que foi possível caracterizar a existência do embasamento da unidade (por evidências petrográficas ou geocronológicas), verificou-se que sua natureza era granítica, de modo que o cinturão orogênico do final do Pré-Cambriano formou-se em região de crosta siálica continental, e não oceânica.

São poucos os dados geocronológicos obtidos diretamente em rochas coletadas na região em questão. Entretanto numerosas determinações de idade, pelo métodos $\mathrm{Rb}-\mathrm{Sr}$ e K-Ar, foram obtidas nas áreas contíguas dos Estados de São Paulo e do Paraná. Cordani e Bittencourt (1967) apresentam uma evolução geológica para as rochas do Grupo Açungui, baseada em cerca de cinqüenta determinações pelo método K-Ar. Aqueles autores situam entre 600 e 650 m.a. a fase orogênica principal, sintectônica, do cinturão Ribeira; além 
disso, mencionam que vários eventos orogênicos, acompanhados de intrusão de granitos tardi a pós-gectônicos aconteceram até cerca de $500 \mathrm{~m}$.a.; finalmente colocam entre 450 e 500 m.a., a fase final de levantamento epirogenético da cadeia montanhosa resultante do ciclo orogênico.

Posteriormente, Cordani e Kawashita (1971), através de determinações Rb-Sr em rocha total nas variedades graníticas intrusivas, confirmam as conclusões do trabalho anterior e situam através de dois gráficos com linhas isócronas em $610 \pm 50$ m.a. a fase tarditectônica, e em $540 \pm 10$ m.a. a fase pós-tectônica principal do cinturão. Cabe assinalar que da isócrona referente aos granitos postectônicos fez parte uma amostra proveniente do maciço do Guaraú.

As relações iniciais $\mathrm{Sr}^{87} / \mathrm{Sr}^{86}$ das isócronas obtidas foram, em ambos os casos, próximas do valor 0,71 , o que sugere a formação dos magmas graníticos a partir do material do próprio cinturão orogênico, ao qual foi adicionada uma fração considerável de material primário, separado do manto durante a evolução da unidade geotectônica.

Com relação à região do Ribeira, ao aplicar-se esquema acima proposto, ter-se-ia a seguinte evolução:

antes de 650 m.a. - sedimentação em ambiente geossinclinal;

cerca de 650 m.a. - fase orogenética principal, e intrusão do complexo de Itapeúna; entre 600 e 650 m.a. - formação dos principais maciços de granitos portiróides, como o de Três Córregos;

cerca de 540 m.a. - intrusões pós-tectônicas, como as do Guaraú e Mandira;

cerca de 500 m.a. - levantamento da cadeia montanhosa e resfriamento regional.

Uma idade aparente de $1380 \pm 45$ m.a., pelo método K-Ar, foi obtida por Cordani e Bittencourt (1967), em antıbólio proveniente ue um gnaisse fitado da serra do Cardoso (rodovia BR-116, Km. 269). Esse dado, significando uma idade mínima para a formação de rocha, demonstra a existência, na região, de material bem anterior ao Ciclo Orogênico Brasiliano.

- Outra idade aparente interessante, que merece ser aqui mencionada, é a referente à biotita de amostra do granito Alto Turvo, coletada no marco quilométrico 305 da rodovia BR-116. Tal determinação, efetuada pelo método $\mathrm{K}-\mathrm{Ar}$, e com resultado de $636 \pm 20$ m.a., foge ao padrão geral, visto que as micas apresentam em geral idades aparentes entre 450 e 500 m.a. Esse dado, que representa uma idade mínima, pode significar que o maciço granítico Alto Turvo seria de natureza tarditectônica, ou, eventualmente, sintectônica. Em adição, não pode ser excluída a hipótese de esse maciço representar, em verdade, uma rocha granítica formada anteriormente ao Ciclo Orogênico Brasiliano.

Finalmente, cabe uma referência às idades $\mathrm{Pb}$ modelo obtidas em galenas da região estudada, e mencionadas por Damasceno e Bettencourt (1968), com valores da ordem de 1100 m.a. Tais resultados indicariam que a mineralização de chumbo do vale do Ribeira seria produzida por meio de remobilização de material contido na infra-estrutura dos metassedimentos, sugerindo mais uma vez a natureza siálica do embasamento da unidade geotectônica.

\section{BIBLIOGRAFIA}

ALMEIDA, F. F. M. de - 1957 - Novas ocorrências de fósseis no pré-cambriano brasileiro. An. Acad. Bras. Ci., 29, 63-72

ALMEIDA, F. F. M. de, AMARAL, G., CORDANI, U. G. e KAWASHITA, K. - no prelo - The Precambrian evolution of the South American cratonic margin, south of the Amazon river. 
In "The Ocean Basins and Margins - The South Atlantic Ocean". Ed. A. E. M. Nairn e F. G. Stehli. Plenum Press.

AMARAL, G., BUSHEE, J., CORDANI, U. G., KAWASHITA, K. e REYNOLDS, J. H. - 1967 Potassium-argon ages of alkaline rocks from southern Brazil - Geochim. et Cosmochim. Acta, 31, 117-142.

BARBOSA, A. F. e PASSOS GUIMARÃES, J. E. - 1946 - Contribuição ao conhecimento da Província Metalogenética da Região da Ribeira, Estado de São Paulo. An. II Congr. Panam. Eng. Minas e Geol., 2, 35-100.

BASTIAN. L. - 1946 - Ocorrências de minério de chumbo em Lageado, Município de Iporanga. Ri.. In-1. Geogr. Geol.. 4, 406-434.

BETTE.NCIOURT, J.S., FÚlFARO, V.J., GIRARDI, V.A. V. e PETRI, S. - 1971 - Geologia da Folha de Capão Bonito, SP - An. XXV Congr. Bras. Geol., 1, 97.

BIGARELLA, J. J. e MOUSINHO, M. R. - 1965 - Significado paleogeográfico e paleoclimático dos depósitos rudáceos. Bol. Paran. Geogr., 16 c 17, 7-16.

BIGARELLA, J. J. e SALAMUNI, R. - 1958 - Contribuição à geologia da região sul da Série Açungui, Estado do Paraná. Bol. Paul. Inst. Geogr., 29. 3-19.

CORDANI, U. G. e BITTENCOURT, I. - 1967 - Determinações de idade potássio-argônio em rochas do Grupo Açungui. An. XXI Congr. Bras. Geol., 218-233.

CORDANI, U. G. e GIRARDI, V. A. V. - 1967 - Geologia da Folha de Morretes. Bol. Univ. Fed. Paraná, Geologia, 26, 1-40.

CORDANI, U. G. e HASUI, Y. - 1968 - Idades K-Ar de rochas alcalinas do primeiro planalto do Estado do Paraná. An. XXII Congr. Bras. Geol., 149-153.

CORDANI, U. G. e KAWASHITA, K. - 1971 - Estudo geocronológico, pelo método Rb-Sr, de rochas graníticas intrusivas no Grupo Açungui. An. XXV Congr. Bras. Geol., 1, 105-110.

CORDANI, U. G., DELHAL, J. e LEDENT, D, - 1973 - Orogenéses Superposées dans le Précambrien du Brésil Sud-Oriental (États de Rio de Janeiro et de Minas Gerais). Rev. Bras. Geoc., 3, 1-22.

CORDANI, U. G., BITTENCOURT, I., BETTENCOURT, J. S., GOMES, C. B., LELLIS, H. S., MELCHER, G. C. e MELFI, A. J. - 1971a - Geologia da Folha de Guapiara, SP. An. XXV Congr. Bras. Geol., 1, 95.

CORDANI, U. G., GIRARDi, V. A. V., GOMES, C. B., LELliS, H.S., MELCHER, G. C. e MELFI, A. J. - 1971b - Geologia da Folha de Eldorado, SP. An. XXV Congrs. Bras. Geol., $1,103$.

DAMASCENO, E. C. e BETTENCOURT, J. S. - 1968 - Idades relativas de mineralização de chumbo de Panelas e de Itapirapuã. XXII Cong. Bras. Geol., Resumo Comunicações, 37.

DELHAL, J., LEDENT, D. e CORDANI, U. G. - 1969 - Ages $\mathrm{Pb} / \mathrm{U}, \mathrm{Sr} / \mathrm{Rb}$, et $\mathrm{Ar} / \mathrm{K}$ des formations métamorphiques et granitiques du Sud-Est du Brésil (États de Rio de Janeiro et de Minas Gerais). Annal. Soc. Geol. Belg., 92, 271-283.

EBERT, H. - 1971 - Observações sobre a litologia e subdivisão do "Grupo Setuva" no Estado do Paraná; com sugestões à tectônica geral do "Geossinclínio Açungui". An. Congr. Bras. Geol., 1, 131-165.

EBERT, H., BROCHINI, M. F. e MARINI, O. J. - 1971 - Observações sobre os gńaisses de "Formação Setuva", Estado do Paraná. XXV Congr. Bras. Geol., Bol. Especial, 1, 185-186.

FUCK, R. A., MARINI, O. J. e TREIN, E. - 1967 - Contribuição ao estudo das rochas graníticas do Estado do Paraná. In "Geologia do Pré-Devoniano e Intrusivas subseqüentes da porção oriental do Estado do Paraná". Bol. Paran. Geoc., 23 a 25, 182-219.

FUCK, R. A., MARINI, O. J., TREIN, E. e MURATORI, A. - 1971 - Geologia do Leste Paranaense. An. XXV Congr. Bras. Geol., 121-130.

FRANZINELLI, E. - 1970 - Estudo sedimentológico da Formação Pariquera-Açu, Estado de São Paulo. Instituto de Geociências, Universidade de São Paulo. Tese de Mestrado (Inédito).

FRANZINELLI, E. - 1971 - Origem e proveniência dos sedimentos da Formação Pariquera-Açu, pelo "Trend Surface analysis" das suas características texturais. An. XXV Congr. Bras. Geol., 267-275.

GEOFFROY, P. R. e SANTOS, T. D. de S. - 1942 - Nota sobre a geologia de Apiaí. Miner. e Metal., VI, n. 33, 109-110. 
GIRARDI, V. A. V. - 1967 - Petrologia das rochas metamórficas da região Morretes-Antonina, PR. Faculdade de Filosofia, Ciências e Letras, Universidade de São Paulo. Tese de Doutoramento (Inédito).

GOMES, C. B. e CORDANI, U. G. - 1965 - Geocronologia do Maciço Alcalino de Itapirapuã. An. Acad. Bras. Ci., 37, 497-501.

GOMES, C. B., BITTENCOURT, I., CORDANI, G. U., FULFARO, V. J., MELFI, A. J.,PETRI, S. - 1971 - Geologia da Folha de Itararé, SP e PR. An. Congr. Bras. Geol., 1, 93.

GOMES, C. B., BITTENCOURT, I., CORDANI, U. G., DAMASCENO, E. C., Lellis, H. S., MELCHER, G. C. e MELFI, A. J. - 1971b - Geologia da Folha de Cerro Azul, SP e PR. An. XXV Congr. Bras. Geol., 1, 99.

LEONARDOS, O. H. - 1934 - Chumbo e prata no Estado de São Paulo. Div. Fom. Prod. Min., 6, 1-47.

MARINI, O. J., TREIN, E. e FUCK, R. A. - 1967 - O Grupo Açungui no Estado do Paraná. In "Geologia do Pré-Devoniano e intrusivas subseqüentes da porção oriental do Estado do Paraná". Bol. Paran. Geoci., 23 a 25, 43-103.

MELCHER, G. C. - 1965 - Contribuição ao conhecimento do Distrito Mineral do Ribeira de Iguape, Estados de São Paulo e Paraná. Tese de Livre-Docência. Escola Politécnica, Universidade de São Paulo. (Inédito).

MELCHER, G. C. e JOHNSON, R. F. - 1956 - Geologia e depósitos minerais do vale do rio Ribeira de Iguape. Div. Fom. Prod. Min. (Inédito).

MEI.CHER. G. C.. CORDANI. U. G.. DAMASCENO, E. C., GIRARDI, V. A. V.,GOMES, C. B., LELlis, H. S. e MLLFI, A. J. - 1971 - Geologia da Folha de Apiaí, SP e PR. An. Congr. Bras. Geol., 1, 101.

MELFI, A. J., CORDANI, U. G. e BITTENCOURT, I. - $1965 \pm$ Reconhecimento fotogeológico de parte do Grupo Açungui. Bragantia, 24, 447-474.

PETRI, S. e FULFARO, V. J. - 1967 - Considerações geológicas sobre a região de Itapeva, SP. Soc. Bras. Geol., 16, 28-31.

PETRI, S. e SUGUIO, K. - 1969 - Sobre os metassedimentos do Grupo Açungui do Extremo Sul do Estado de São Paulo. Secr. Serv. Obras Públicas, D.A.E.E., Serv. Vale Ribeira, 1-98.

SILVEIRA, J. D. - 1950 - Baixadas litorâneas quentes e úmidas. Faculdade de Filosofia, Ciências e Letras, Universidade de São Paulo. Tese de Cátedra (Inédito).

TURNER, F. J. - 1968 - Metamorphic Petrology - Mineralogical and Field Aspects. McGrawHill Book Co., New York. 